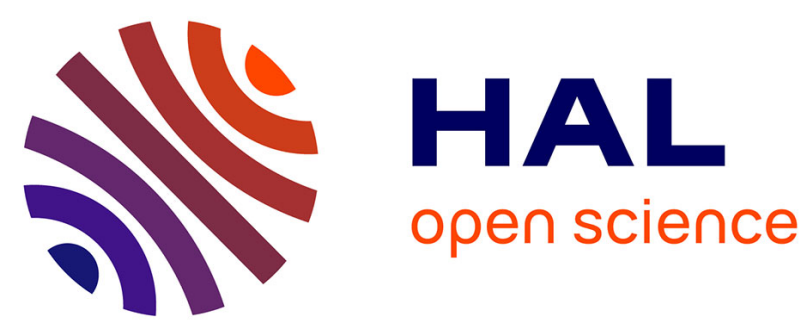

\title{
Humusica 1, article 7: Terrestrial humus systems and forms - Field practice and sampling problems
}

\author{
Augusto Zanella, Jean-François Ponge, Magali Matteodo
}

\section{To cite this version:}

Augusto Zanella, Jean-François Ponge, Magali Matteodo. Humusica 1, article 7: Terrestrial humus systems and forms - Field practice and sampling problems. Applied Soil Ecology, 2018, 122 (Part 1), pp.92-102. 10.1016/j.apsoil.2017.05.028 . hal-01661215

\section{HAL Id: hal-01661215 \\ https://hal.science/hal-01661215}

Submitted on 11 Dec 2017

HAL is a multi-disciplinary open access archive for the deposit and dissemination of scientific research documents, whether they are published or not. The documents may come from teaching and research institutions in France or abroad, or from public or private research centers.
L'archive ouverte pluridisciplinaire HAL, est destinée au dépôt et à la diffusion de documents scientifiques de niveau recherche, publiés ou non, émanant des établissements d'enseignement et de recherche français ou étrangers, des laboratoires publics ou privés. 


\title{
Humusica 1, article 7: Terrestrial humus systems and forms - Field practice and sampling problems
}

\author{
Augusto Zanella $^{\mathrm{a}, *}+$, , Jean-François Ponge ${ }^{\mathrm{b}}$, Magali Matteodo ${ }^{c}$ \\ ${ }^{a}$ University of Padua, Padua, Italy \\ ${ }^{\mathrm{b}}$ Muséum National d'Histoire Naturelle, Paris, France \\ c Université de Lausanne, Lausanne, Switzerland
}

Keywords: Humus; Humus systems; Soil field practice; Soil sampling; Soil functioning

\section{ABSTRACT}

The present paper should be read after the six preceding articles dealing with fundamental concepts, vocabulary, principles and keys of our morpho-functional classification of humus systems and forms, the whole book being conceived as a guide for field studies. It now concerns seven questions which may arise when passing from knowledge to practice or, in other terms, from concepts to real things. In the field, humipedons can differ from reported photographs. Trees, bushes and/or herbs interfere with soil functioning and may generate different humipedons even over a relatively small surface. More generally a researcher must select a few unit plots representative of a given natural floor for defining the frame of his investigation. In this article, authors present some practical and theoretical landmarks and illustrate some solutions for studying humipedons in common natural sites, and replacing them within ecosystem dynamics.

\footnotetext{
* Not cited author of figures. Music while reading ? by Guido Fichtner, Paganini - The 37 guitar sonatas: http://www.youtube.com/watch?v=JVbA70FCpgA

${ }^{\dagger}$ Corresponding author.

E-mail addresses: augusto.zanella@unipd.it (A.Zanella), ponge@mnhn.fr (J.-F. Ponge), magali.matteodo@unil.ch (M. Matteodo).
} 


\section{What are humus systems and humus forms?}

Let's put a glance to the superficial soil, in a forest, a meadow or a garden. With a spade, cut a pit to see the soil with the naked eye, without any instrument other than your glasses, if any. What do you see?

Colours are not distributed at random. More generally, the colour of the soil becomes clearer from the top to the bottom of the soil profile thus revealed. These colour changes indicate how organic matter is distributed throughout the soil. Original molecules with a high content in carbon (cellulose, hemicelluloses, lignin, pectin,) are white - they reflect the light - or transparent - light pass through them, but humification confers to transformed (oxidized, condensed) molecular assemblages a more or less dark colour: losing its crystalline properties, this organic mass absorbs the light and thus is dark to the naked eye (Kumada, 1987). The amount of organic matter decreases with depth: the successive layers, which differ at first glance by their colour but also by their structure, composition and chemical and biological properties, are called horizons (for definition and classification of horizons see Humusica 1, article 4). A more thorough examination will reveal some components which indicate soil life: roots of varying size, aggregates of varying shape and size, sometimes cavities created by earthworms and other animals. All these features characterize superposed soil horizons, made of pure organic matter, such as plant remains, intact or more or less decayed, at the top of the profile, black or brown in accordance with their high carbon content, becoming more mineral and lighter at the bottom of the humipedon. In fact, every natural site is characterized by its own series of horizons, the more distant the sites in terms of climate, vegetation/fauna, water availability, etc., the more different in number and colour the series of horizons (Targulian and Krasilnikov, 2007; Zanella et al., 2011; Labaz et al., 2014). Each series of horizons corresponds to a humus form.

There are similarities among humus forms developing in similar environments and the most important endeavour of humus form specialists in the last century has been to classify humus forms, i.e. series of horizons, in a few morpho-functional units called humus systems (see Humusica 1 , article 5). It allowed better circumscribing and understanding their functioning. By comparing field series of horizons with the references set up in this manual you will rapidly be able to find the name of the humus systems and often the more precise name of the humus forms (Fig. 1a, b).

Now, with these simple notions in mind, you can compare several places in the same forest, differing at first sight by luxuriance and variety of the vegetation. Say, for West-European people, a well-stratified oak-hornbeam forest with a dense and diversified shrub layer and intense spring flowering on one part, and a poorly stratified birch-oak forest with a monotonous layer of bracken covering the ground on the other part. By digging the soil to 10 or 20 or more rarely $30 \mathrm{~cm}$ you will discover two opposite kinds of humus form (Figs. 2a, b). In the former case (Fig. 2a), a thin layer of dead leaves (sometimes totally disappearing in summer) gives place abruptly to a brown crumby horizon made of small aggregates $(1-10 \mathrm{~mm}$ ) visibly made of a tight mixture of organic, darkcoloured and mineral components: sand particles glitter under sunlight, but can be also perceived by squashing aggregates with fingers. This is a typical earthworm earth, where aggregates, called macroor meso-aggregates according to their size, are faeces of earthworms having mixed organic (leaf and root litter) with mineral matter (the underlying soil). In the latter case (Fig. 2b), under a more or less thick layer of dead leaves, there are other horizons made of pure or near pure organic matter: a 
horizon of more or less decayed (often fragmented) leaves, permeated by fungal threads and roots and spotted with small dark deposits, overlays a dark horizon where these small dark deposits (in fact faeces of tiny litter-consuming animals) become dominant. Below these organic horizons, there is a progressive transition to a horizon made of organic and mineral matter, but without any signs of macro- or meso-aggregation. Through a magnifying lens, you can see that the soil of this horizon is made of thin $(<1 \mathrm{~mm})$ aggregates mixed with mineral grains. We know by the use of microscopic methods that these micro-aggregates are made by small $(<1 \mathrm{~cm}$ in length) transparent worms called enchytraeids, which are very abundant but difficult to observe in the field by the naked eye (Figs. 3a, b).

These two distinct "patterns" are good indicators of vegetation composition, biodiversity and productivity (Ponge and Chevalier, 2006; Lalanne et al., 2008) and for this reason they are called humus systems. This means that looking carefully to the morphology of topsoil horizons allows us to obtain useful information about the functioning of the whole ecosystem. In the two-abovementioned examples, the former pattern, Mull indicates a faster recycling of nutrients and a higher biodiversity and productivity than the latter, Moder (Ponge, 2003).

In the Humusica manual we present 10 typical, well-developed humus systems ( 5 in welldrained soils, 5 in wet soils), 4 atypical humus systems (young, incipient soil profiles or developed in particular or harsh environmental conditions) and 2 groups of anthropogenic Humipedons (seminatural agricultural soils and artificial composts/manures). The aim of the authors of this guide is to teach even untrained people how to classify a Humipedon at the level of the humus system and when possible to the humus form.

Finally, a humus system (or humus form) corresponds to a particular sequence of diagnostic horizons the morphology of which is observable by naked eye or with the help of a 5-10 x magnifying lens. Each humus form contents information about the functioning of the whole ecosystem, because the topsoil is the seat of key processes of organic matter and nutrient recycling.

\section{Where and how to find humus forms?}

Humus forms can be found everywhere life is present, and where organic matter and mineral matter are interfering. For water body sediments, other concepts are in use and very little is still known about life under water. Humus forms can be found everywhere, from seashores to mountain summits, from desert to polar biomes. The concept of humus form embraces not only well-aerated deposits (called Terrestrial humus forms) but also those saturated with water (called Histic humus forms), including the organic and mineral matter accumulated in bogs and fens. As proposed in the present book the concept of humus form can be extended to atypical forms (labelled Para humus forms) such as biological crusts of granitic outcrops, deserts, tundras, and other areas covered with cryptogamic vegetation, i.e. everywhere organic matter may accumulate even in the absence of a real soil profile. Some environments exist, where organic matter has not been deposited on the ground but above it, on tree trunks and canopies (suspended soils with epiphytic vegetation), boulders, walls or building roofs. In all these cases horizons can be described according to the stage 
of decomposition and humification of plant remains, whether cryptogamic or phanerogamic. It must be noted that humus forms can be described and classified even if the soil does not exist or cannot be described or has not been so far described (Figs. 4a, b).

\section{How carefully to observe humus forms?}

The naked eye, eventually aided with a portable magnifying glass, allows easily discerning details to a tenth $\mathrm{mm}$, the size of fine sand grains (see more details in Humusica 1, article 4). This is enough to discern faecal pellets deposited by most soil-building animals (Figs. 5a, b), to the exception of those of small enchytraeid worms, the size of which is often $\leq 50 \mu \mathrm{m}$ (Ponge, 1999). Enchytraeid faeces are roughly isodiametric and poorly compact and form a fine dark powder which, when moistened, becomes compact and looks like a sticky paste. Thus traces of enchytraeid activity are often overlooked by field observers, despite the functional importance of this group. Oribatid mite faeces are roughly of the same size but their compactness and bullet-like shape make them much easier to identify on the field (Ponge, 1991b). The assessment of animal activity is a key point of observation (see Humusica 1, article 8). Animal feeding and defecating activities are the only mean by which plant remains are transformed in an "amorphous" mass of humus, even if bacteria and fungi are the only "true" decomposers (Moore and Hunt, 1988).

Observing humus forms means using our eyes for identifying horizons and measuring their thickness, but also taking each horizon in the palm of the hand and gently squashing its components between our fingers (examples in Humusica 1, article 4). This is the best means to separate components which are physically fastened or agglomerated in components of larger size (Elliott and Coleman, 1988). The fractal dimension of the soil implies a hierarchical assemblage of smaller soil components embedded in larger ones, along an endless chain (Coleman et al., 1992; Ponge, 2015).

Observing transitions between horizons requires a good knowledge of what is a horizon (see Humusica, article 4). A horizon is formed by the accumulation of components of a given nature, generally associated with some dated process of formation (Buol et al., 2011). Although soil and, in it, every horizon, is heterogeneous, the fact that litter is only or mostly shed in a given season (this can be observed even in coniferous forests) generates a layer of more or less intact plant organs which, in the following, will undergo changes roughly at the same rate: they will become fragmented, then humified in bulk, most probably at the same season (to the exception of some recalcitrant remains harder to transform). Each layer formed in this manner in a humus profile can be dated (Bernier and Ponge, 1994) and associated to an event (the fall of plant debris) and further transformations which, being biological in main, are strongly submitted to seasonally changing factors (temperature, moisture). The horizon is thus an emergent property of plant-soil relationships, resulting from the magnification of tiny processes of transformation of organic matter in which plants, animals and microbes are involved in a coordinated manner (Ponge, 2005, 2015). As a consequence, the more seasonal are litter inputs and transformations, the more abrupt will be transitions between horizons. The same holds true for mineral-organic horizons, but the seasonality is here more that of soildwelling animal and microbial activities than that of plant phenology, to the exception of root systems and their mycorrhizal associates which are a driving force of vertical heterogeneity (Ponge, 
2000). Amphi is a good example of how seasons build-up horizons, by separating the humus profile in two compartments (see Humusica 1, article 5 ). The upper, organic horizon is only available to burrowing animals during a short mild (warm, moist) season, while the lower, mineral-organic horizon is a refuge used during less favourable (cold, dry) seasons. Here climate, and not litter fall, generates horizons. The behaviour of soil engineers, like earthworms, termites or ants (Lavelle, 2002), is also determinant in the build-up of horizons and in determining their upper and lower limits (Bernier, 1998). Each earthworm species has its own preferences in feeding resources and vertical placement, stemming in a domain of activity out of which its action will be negligible. These functional domains (Lavelle, 2002) stem also in horizons, but the complexity of soil trophic networks (many functional domains are intermingling) does not contribute to abruptly delineate horizons within the zone where organic matter is mixed with mineral matter: generally only one mineralorganic horizon $(A)$ is recognized, the structure of which is determined by the activity of a dominant (generally larger) faunal group (Topoliantz et al., 2000).

\section{Why and how humus forms build-up?}

\subsection{Prelude}

"Why am I growing up, dad?"

"I don't know, we grow up, become old, and die. Nobody knows why."

Interrogative eyes: “......?”

"A general attraction sticks together particles and forms larger bodies. A guy like you, eats and grows.

"Then?"

"Then, you'll stop growing and become old".

"Why do we die, in the end?"

"We are like card towers; there is a moment they crash down."

" ....dad, with plastic blocks, I can build higher towers".

Door opens. Mam: "Time for lunch!"

\subsection{Strategies}


A recycling process occurs at many scales of matter complexity. In a forest, an immense number of organisms grow, reproduce and die. Life strategies may be set in " $r$ " or " $\mathrm{K}$ " categories (MacArthur and Wilson, 1967). Experimental and meta-analytical results allowed Fierer et al. (2007) to differentiate copiotrophic and oligotrophic categories of bacteria, which correspond to the $r$ - and $\mathrm{K}$-selected categories used to describe the ecological attributes of plants and animals. By applying the copiotroph-oligotroph concept to soil microorganisms, these authors made a first step toward a better understanding of the soil functioning. Under apparent optimal conditions, oligotroph bacteria grow slowly because adapted to environments with low levels of nutrients. As larger organisms, copiotroph and oligotroph bacteria live side by side in the soil, exploiting different space-time niches. In general, both " $\mathrm{r}$ " or " $\mathrm{K}$ " theoretical strategies may be considered as approaches for increasing an ecosystem complexity. The final decomposition in the soil of this complexity looks like a nonsense. The process of evolution corresponds to a string of falling card towers (as in prelude). As for the main principle of energy conservation, the variety of means employed for exploiting a given amount of energy does not increase the starting amount of it. Strategies can only stretch the way and delay a common deadline (in-depth analysis: Zanella A., "Humans, humus and Universe", in Humusica 3). Whatever the strategy, organisms have to die and continuously feed a soil sink, which works like a mincer neck (Fig. 6). Only small molecules overpass the opening. Having a step back and looking at the process of evolution with a larger horizon, it appears that a "digestive equipment" is mandatory for the functioning of a living system at any scale. Examples: a) digestion of food (belly as a controlled soil), even apoptosis; b) meiosis, with DNA crossing-over and exchange and gamete formation; d) organisms' reproduction and death; e) complexification/destruction of ecosystems; e) soil mineralisation/humification, which could be a process of digestion at microorganism scale that closes the cycle of a huge, planetary macro-evolution. Why humus forms build-up? Because they correspond to "soil strategies", i.e. soil organised (not casual) living relationships to efficaciously extract energy and nutriments from ecosystems' rests, in a given environment. Humus systems and forms are trailblazing means for understanding a soil functioning.

\subsection{Microorganisms}

Gordon Gulch is an upper montane forest (average elevation $=2627 \mathrm{~m}$ ) in Colorado (USA). Eilers et al. (2012) discovered that the microbial communities living at different depths in 9 soil profiles $(0-180 \mathrm{~cm}$ ) of two (north and south facing slopes) Gordon Gulch pine forests, develop magnitude changes (amplification of the hypervariable V4 region of the 16S rRNA gene from bacteria and archaea) comparable to the one found with the same methods in microorganisms of 54 surface soils $(0-5 \mathrm{~cm})$ collected from locations throughout North and South America.

\subsection{Ecosystems}

Similar to a large organism, every terrestrial system can grow until a limit imposed by the amounts of available energy, water and mineral elements, the highest near the Equator (tropical 
biomes), the lowest near the poles (polar biomes). Historically, each ecosystem passes through a series of stages, from the naked rock poor in microorganisms to ecosystems richer in mosses or lichens, then grasses, then shrubs, and finally high trees, the whole process taking centuries to completion if allowed by climate and in the absence of severe disturbance (Odum, 1969). The more the system is complex and productive, the more the process of feeding the soil with dead organic matter goes on faster. The consequence is the establishment of an increasing flow of nutrients through the system, from above- to below-ground and vice versa (Ponge, 2013). The primary source of energy that allows the system to run is sunlight, providing organic matter thanks to photosynthesis. The secondary source stays in the soil under the form of decaying organic matter, slowly delivering its energy according to a process of controlled oxidation and condensation, called humification (Kumada, 1987). In the soil, the process of transfer of the structural energy of this organic matter is distributed in layers, made of fresh organic matter at the top, and of well-degraded and transformed material at the bottom. As mentioned above, we call this superposition of organic and organic-mineral layers the humus profile.

Photosynthetic plants, from cyanobacteria to tall trees, provide organic matter to the soil, which becomes food and habitat for soil-dwelling organisms. First, leaves, needles and other aerial plant organs fall on the ground, where they form a more or less continuous layer (Fig. 7). According to its progressive transformation by microbial and animal decomposers (Ponge, 1991a) several horizons may appear, recently fallen plant remains visible year-round (needles, perennial leaves) or just at leaf-fall (deciduous leaves) overlying aged remains. Once plant remains are penetrated and transformed by fungal mycelia, animals feed on leaves, leaving behind their faeces (pellets or smears), which are deposited at the surface of or between plant remains, then accumulate if not consumed by animals of bigger size. Leaf and needle remains progressively disappear (they are decomposed and/or included in animal faeces), while fine roots proliferate and die in turn or grow to woody perennial subterranean systems.

Authors compared the soil to a giant rumen, digesting organic matter for sustaining life and nourishing primary producers (plants), their consumers (herbivores) and predators, with strong analogies in microbial processes taking place in rumens such as cellulose decomposition and nitrogen fixation (Chesson, 1997). Animal faeces are in turn the seat of an intense microbial activity and, when animals and microbes die, their remains become incorporated to the soil organic matter, forming what is commonly called "humus". As a result, horizons are formed when and where organic matter has been transformed into an amorphous mass of humus (in chemical sense), partly of plant origin, partly of microbial origin, and for a little part of faunal origin (Stevenson, 1994).

Despite their feeble contribution to soil metabolism (Macfadyen, 1963), decomposer (saprophagous) animals play a decisive role in the transformation of organic matter in the soil, given the intensity of their feeding activities in litter (Ponge, 1991b) and in underlying soil horizons (Lavelle, 2002). According to parent material and dominant types of animal activity, whether burrowing or not, humus in chemical sense may or may not be mixed with mineral matter, giving rise to a variety of humus forms. Chemical and physical links of humus compounds with clay particles and metal oxides are particularly stable (Wang et al., 1986), contributing to the long-term sequestration of soil organic carbon (Martin, 1991). In the absence of burrowing animals (earthworms, ants, termites, tenebrionid larvae, but also vertebrates such as moles and voles), raw or humified organic matter accumulates as organic horizons overlying mineral or mineral-organic horizons. For climatic reasons, 
organic matter may also accumulate as distinct horizons even in the presence of an intense burrowing activity. This is the case where the mineral richness of the parent material is able to sustain burrowing animal populations (carbonated rocks or siliceous rocks with a high content in weatherable minerals), but climate is seasonally too dry (Mediterranean regions) or too cold (high mountains) to allow them processing litter year-round: here is Amphi (Galvan et al., 2008; Andreetta et al., 2011), previously classified as Amphimull (Tagger et al., 2008) and often misidentified as Mor or Moder (for instance Xeromoder) because of the prominent thickness of organic horizons (Pinzari et al., 2001).

\section{Where and when humus forms are changing?}

As suggested above, humus forms result from the interplay between parent rock, climate, vegetation and soil life (Ponge, 2003; Labaz et al., 2014) and they mediate most well-known plant-soil feedbacks (Targulian and Krasilnikov, 2007; Ponge, 2013). Geology and climate have been identified as main drivers of humus form changes at large scale (Ponge et al., 2011) while at small scale vegetation seems to play a decisive role in humus form heterogeneity (Kounda-Kiki et al., 2008). Any change in one or several of these drivers will result in a change in humus form (Fig. 8), as it can be observed along geological transitions or catenas (Klinge, 1965), altitudinal (Bednorz et al., 2000) or latitudinal gradients (Takeda, 1998) and within vegetation mosaics (Emmer, 1994). Vegetation dynamics, either successional (Emmer, 1995) or cyclic (Bernier and Ponge, 1994), is reflected in shifts in litter quantity and quality which in turn influence humus forms through their impact on soil animals, in particular the most sensitive of them, the earthworms (Bierkens et al., 1998). Thus time is another important parameter to be taken into account, space-for-time substitution studies suggesting that changes in humus forms, visible over decades of the forest cycle (Bernier and Ponge, 1994), are much more rapid than changes in soil types (Dimbleby, 1962; Willis et al., 1997).

Humus forms can be imagined in a landscape of ecological attractors as portrayed in Figure 9 , the ecosystem falling in several possible "holes" (ecological attractors) like a golf ball in a green (Zanella et al., 2001, 2009; Graefe and Beylich, 2006; Ibáñez et al., 2012). Thus, feeble climatic and nutritional constraints may attract the ecosystem to a Mull hole (humid tropical or mesic temperate climates), while conditions unfavourable to anecic earthworms will push the system to a Moder hole (mountain, boreal or acid areas, or areas/periods of intense tree growth). Very unfavourable conditions for animal and microbial activity are typical of a Mor hole (high latitude, high altitude, strong acidity). Seasonally harsh conditions (drought, frost) on nutrient-rich substrates lead to an Amphi hole (Mediterranean forests, subalpine forests on nutrient-rich soils), while more permanently unfavourable conditions on nutrient-rich substrates bring the system towards a Tangel hole (high mountain calcareous south-exposed sites).

This landscape is not seen only at regional scale, because humus forms are also sensitive to small-scale events. A forest characterized by a Moder humus form can switch locally (and temporarily) to Mull when foresters open the canopy: the consequent increase in available light and moisture activates soil microorganisms and fauna, the humus form evolving in a few years through the steps of the imaginary ecological relief of Figure 9, "climbing" from Eumoder to Hemimoder and 
then "falling" into Mull hole through Dys- or Oligomull and even joining sometimes a Eumull central form. The process is reversed, indeed, when the tree canopy recovers and the intensively growing tree population impoverishes the soil in nutrients for building its aerial biomass, resulting in a decoupling between rates of decomposition and nutrient uptake (Ulrich, 1986).

Whether present-day rapid climate warming is reflected in humus forms is still a matter of conjecture, although observed and predicted latitudinal and altitudinal shifts in species distribution (Chen et al., 2011) suggest it be the case. Ponge et al. (2011) calculated on the base of present-day distribution of humus forms along a temperature gradient that an increase of $3{ }^{\circ} \mathrm{C}$, predicted to occur from 2000 to 2050 (Cox et al., 2000), would correspond to a decrease of the Humus Index (Ponge et al., 2002) of one unit, i.e. according to the scale considered a shift from Mesomull to Eumull, or of Dysmoder to Eumoder. Such a prediction has evident limits, because two factors are not accounted for, (i) the immigration of functionally important species with poor dispersal abilities, such as earthworms (Marinissen and Van den Bosch, 1992), and (ii) predicted vegetation changes in favour of plants with more recalcitrant litter types (Cornelissen et al., 2007). Whatever the rate at which such changes are expected to occur, we have still to find reliable indices of the direction of change in humus forms. As an example, observations made by Bernier and Ponge (1994) along spruce forest chronosequences showed shifts from Moder to Mull, following the immigration of burrowing earthworm species below mature and senescent spruce stands. That humus form change was indeed in this direction was suggested by remaining pockets of organic, well-humified $(\mathrm{OH})$ horizon within a crumby mineral-organic (A) horizon. Indices of this kind should be recorded and classified as diagnostic tools for forwarding future humus forms and accompanying changes such as increases or decreases in soil carbon stocks (De Nicola et al., 2014).

\section{At which scales humus forms can be investigated?}

A general terrestrial ecosystem is made of humus systems and forms which occupy the landscape as tri-dimensional covers (Klinka et al., 1981). Enclosing ecosystems in imaginary boxes (arbitrarily represented as cubes) gives a physical space to the system, helping better understanding the phenomena taking place at its inside. Dimensions and orientation of each imaginary box depend on scale of the study. If the reader is interested at describing fine-scale processes, for example how particular plant species might influence the underlying humus form, the imaginary box will include only a circumscribed plant species assemblage. Figure 10 shows a mosaic of two different humus forms belonging to the same humus system: 1$)$ a Pachyamphi $(\mathrm{OH} \geq 3 \mathrm{~cm}$ under low shrubs of Erica carnea; 2$)$ a Eumesoamphi $(\mathrm{OH}<3 \mathrm{~cm})$ under herbaceous vegetation rich in grasses. The general humus system is Amphi, but following variation in vegetation composition it switches between the forms Pachyamphi and Eumesoamphi. In this forest, a detailed study at the scale of the humus form can reveal local effects of the dominance of Erica carnea in the mosaic. Ericaceous heaths within forests have been often observed to impede tree regeneration (reviewed in Royo and Carson Walter, 2006) and a fine definition of soil biological functioning at the level of humus forms is mandatory for having a good knowledge of forest dynamics (Bernier and Ponge, 1994). Imaginary $50 \mathrm{~cm}$-side cubes are sufficient for investigating the soil at this level; differences in many humipedon characteristics (horizon thickness and colour) are visible by naked eye even in the picture. 
Now, the reader might be interested to zoom out from the particular plant species and describe the forest ecosystem as a whole. In this case, the imaginary box has to be bigger enough to embrace a mosaic of plant assemblages and, very likely, a corresponding mosaic of humus forms. The level of investigation will depend again on the study scale, going from a detailed description of humus forms associated to various plant assemblages to a description of dominant plant assemblages. As humus forms may slightly vary within the same plant assemblage (e.g. horizon thickness), a detailed study can even include descriptions of several humus forms in each plant assemblage. Once all (or the main) plant assemblages have been identified and their respective humus forms have been described, one can attribute a composite humus form reference to the forest ecosystem according to the surface ratio covered in the box by each single unit (Fig. 10). This reference can be called "mosaic-reference" to distinguish it from the single humus form reference, which is attributed to a single humipedon. It must be clear that humus systems and forms do not build "mixed" units but stay side-by-side or are superposed (case of Rhizo or Ligno systems vertically mixed with other humus systems), forming composite systems, not mixed ones.

Box 1 of Figure 11 and Box $1 \mathrm{~b}$ within it are heterogeneous and contain a mosaic of plant communities and humus forms which are visible by naked eye. In these cases, if for practical reasons a single reference is required (e.g. for mapping the area), it is possible to consider the ratio of surface covered in the box by each single unit (Fig. 12). According to the examples reported in Figure 12, we can give a composite name to the humus system in Box 1 of Figure 11. Suppose we diagnose a Mull humus system in $1 \mathrm{c}$ and a Moder system in $1 \mathrm{a}$, then we will diagnose a Moder-Mull system in $1 \mathrm{~b}$ and even in the whole Box 1.

Box dimensions may vary according to the studied ecosystem, according to scales at which humus forms and systems have been shown to vary on the field (Cambardella et al., 1994; Niemelä et al., 1996). In forest ecosystems the more practical imaginary boxes for investigating humus forms are $50 \mathrm{~cm}$-side cubes, while $100 \mathrm{~cm}$-side cubes can be used in more uniform ecosystems such as meadows and agricultural fields (examples in Figs. 13a-d), and smaller boxes (1 to $10 \mathrm{~cm}$-side cubes) in small Para systems such as Crusto and Bryo (see Humusica 2, article 13).

\section{Do we need classifying all humus forms observable on the field?}

Jean-Marie Géhu, an unforgettable professor of phytosociology (Braun-Blanquet, 1964) at the University of Paris, was able to detect imperceptible variations in the composition and functioning of plant communities (Géhu, 1980, 1991, 1992; Géhu and Rivas-Martinez, 1981). Even a very weak depression in the soil (few centimetres) was at the origin of a change of vegetation on the forest floor, accompanied by slight variations in soil characteristics $(\mathrm{pH}$, texture, structure, water content, etc.). His envision of small-scale variations in the composition of plant communities pushed some of his disciples to found a new phytosociological system of classification (Gillet et al., 1991; Gillet, 2000). The new plant communities detectable within the classical associations were called "synusia", strictly assigned to different layers of vegetation. According to these principles, single plant species are forming synusia (vegetation layers, distributed in patches), synusia are building associations, which constitute alliances and so on until covering the whole planet. Despite his ability to detect small-scale 
variations, Géhu was fiercely dissident from this new movement. He considered that an excessive partition of the units of reference could destroy an historical and patiently built phytosociological construction (Géhu, 1991, 1996).

The analogy with our hierarchical view of humus forms and systems is self-evident. Humus forms are everywhere and should be classified at various scales, as explained above. As for vegetation, we have to select the best scale of investigation and, given a "mesh size" (the imaginary box), where to dig the soil for finding the humus form. As in all fields of applied science, we have to find and accept the "less bad" compromise for taking decisions and practical actions. In phytosociology, the number of described plant communities (associations, sub-associations, synusia and many "variants" of them) increased out of proportion and this applied science is now at a risk to disappear. Quite the same destiny is probably occurring in soil classification, if people do not understand that an infinite number of soil types is useless and even dangerous.

In Humusica we present 20 humus systems (5 Terrestrial, 5 Histic, 2 Aqueous, 5 Para and 2 Anthropogenic), easy to detect in the field thanks to main soil characteristics visible by naked eye. By simply measuring the thickness of a few diagnostic horizons it is possible to go further and discover even a few humus forms in each system, allowing understanding the cyclic dynamics of litter accumulation and biodegradation. It is evident that the scale at which a complex system is defined will dramatically influence our classification tools. This article takes into account the humipedon scale and gives classification instruments adapted to it. However, we may wonder whether it is reasonable to attribute a unique humus form name to an entire ecosystem, like plant ecologists do with phytosociology (Van der Maarel, 2005). In this context, the attempt of assigning a humus form name to an entire forest ecosystem can be seen as a first step towards a new discipline, that we may call "humus-sociology". But, does it make sense? Can we say the same for the humus forms forming a mosaic in a forest ecosystem (Figs. 11 and 12)? Which is their level of interaction? Which is the relationship between a Bryo-Moder under a moss cushion and a Moder a few centimetres apart? Some exchange of material is likely, but what is its role in terms of ecosystem functioning? These questions remain poorly studied up to now, and are reported here only to encourage reflections and discussions. Their answer will certainly influence the pertinence of a hypothetical "humus-sociology". Other methods for typifying mosaics of humus forms could be suggested, for example by considering the percentage of soil surface occupied by each humus form unit or by calculating an average Humus Index (Ponge et al., 2002). We have to be aware that no method will perfectly reflect the system complexity and we must choose the one that minimize the loss of information.

It is current, even for trained people, to be puzzled with some humus forms for which the use of customary keys is a complete failure. Are they novel to science? Do they result from a disturbance which affected well-known humus forms? Or do we need to consider them as intermediate or transitional forms which cannot be included in any extant classification? Each of these opportunities must be examined. But, first, we must address the conditions needed to be in the presence of a humus form and not of a fortuitous assemblage of organic and/or mineral components. We are in the presence of a humus form when and where the building of horizons result from the equilibrium between by-products of vegetation growth (litter inputs) and their transformation by microbial and animal processes taking place in the topsoil. The humus form is the physical result of these processes in the form of vertically stratified horizons. It must be put to evidence that the absence of any extraneous disturbance (disturbance by agents other than those commonly acting within the humus 
profile) is a necessary condition for the development of a vertical stratification, i.e. of horizons. Whether resulting from logging truck traffic, wild boar digging, or just wind blows, any side displacement, either by addition or subtraction, will disturb or check the formation of a horizon, because a horizon needs time to be constructed. When speaking of humus, we are always faced to augmentative (accumulative) processes allowing passing from micro-processes only visible to the microscope (say, for example, the deposition of a faeces by a springtail) to macro-processes visible on the field to the naked eye (the accumulation of myriads of faeces forming a layer). This is a universal phenomenon known as emergent properties (Ponge, 2005). When tiny unit components aggregate (for instance as a result of reproduction or crowding but also of physical processes such as sorting by particle size or density when water percolates) and form more or less homogeneous masses, then properties appear, which differ from the properties of unit components. These masses once formed may act on the environment and, among others, on the observer's eye, which is now able to "see" them with a reasonable degree of confidence, while unit components remain hidden and/or inactive before "magnification" took place.

All that means that for a horizon to appear, matter must assemble itself, and this needs time and quietness. Quietness does not mean absence of movement, rather absence of displacement by external agents of what has been constructed or is in way to be constructed by soil organisms. External agents of disturbance, whether anthropic or "natural", impede to some extent or at best delay the building of humus forms, and at worst destroy them. By this way "perturbohumus" or truncated humus forms may appear, in the same manner truncated soils appear following some erosion event. In this case, we must not be surprised to become puzzled in face of humus profiles from which some horizons are seemingly "lacking". Do we have to name them? At first sight, we would say "no" because this is a dead end and even more a dangerous initiative. However, we can describe them if some horizons are still visible. If the disturbance is such that horizons are broken up and the whole profile cannot be analysed accurately, then we must be conscious to be in the real world, where things are fuzzy and our knowledge still imperfect, and not in a test case.

At last, we must examine the problem of possible intermediate humus forms. Although the proposed classification allows a wide range of humus forms to be classified on the base of the thickness of litter layers and/or the structure of the A horizon, it remains still possible that some forms were not taken into account, being unknown or rarely encountered. This is mainly the case in high mountain humus forms belonging to the group Mor-Moder-Tangel-Amphi where much more investigations remain to be done, on various geologic and aspect conditions. What happens also when the parent rock is blocky? What happens when the only visible humus is in crevices as in karstic environments? Can we identify humus forms in suspended soils of tropical rain forests? And what about city environments such as roofs covered with plants, pavements, etc. And, even more important, what about agricultural soils which are disturbed all along the year by tillage, pesticides and fertilizers? In these soils defined structures can be identified, varying according to agricultural systems, but litter layers are generally absent (Topoliantz et al., 2000). This is a hard task to achieve, but endeavour is in way and the envision of humus forms as dynamic forms needing time to be elaborated but also prone to evolve under changing environmental conditions or disturbances may help to fill the gaps. 


\section{References}

Andreetta, A., Ciampalini, R., Moretti, P., Vingiani, S., Poggio, G., Matteucci, G., Tescari, F., Carnicelli, S., 2011. Forest humus forms as potential indicators of soil carbon storage in Mediterranean environments. Biol. Fertil. Soils 47, 31-40.

Bednorz, F., Reichstein, M., Broll, G., Holtmeier, F.K., Urfer, W., 2000. Humus forms in the forestalpine tundra ecotone at Stillberg (Dischmatal, Switzerland): spatial heterogeneity and classification. Arctic Antarctic Alpine Res. 32, 21-29.

Bernier, N., Ponge, J.F., 1994. Humus form dynamics during the sylvogenetic cycle in a mountain spruce forest. Soil Biol. Biochem. 26, 183-220.

Bernier, N., 1998. Earthworm feeding activity and development of the humus profile. Biol. Fertil. Soils 26, 215-223.

Bierkens, J., Klein, G., Corbisier, P., Van Den Heuvel, R., Verschaeve, L., Weltens, R., Schoeters, G., 1998. Comparative sensitivity of 20 bioassays for soil quality. Chemosphere 37, 2935-2947.

Braun-Blanquet, J., 1964. Pflanzensoziologie: Grundzüge der Vegetationskunde, 3rd ed. Springer, Wien.

Buol, S.W., Southard, R.J., Graham, R.C., McDaniel, P.A., 2011. Soil Genesis and Classification, $6^{\text {th }}$ ed. Wiley-Blackwell, Chichester.

Cambardella, C.A., Moorman, T.B., Novak, J.M., Parkin, T.B., Karlen, D.L., Turco, R.F., Konopka, A.E., 1994. Field-scale variability of soil properties in Central lowa soils. Soil Sci. Soc. Am. J. 58, 1501-1511.

Chen, I.C., Hill, J.K., Ohlemüller, R., Roy, D.B., Thomas, C.D., 2011. Rapid range shifts of species associated with high levels of climate warming. Science 333, 1024-1026.

Chesson, A., 1997. Plant degradation by ruminants: parallels with litter decomposition in soils. In: Cadisch, G., Giller, K.E. (Eds.), Driven by Nature: Plant Litter Quality and Decomposition. CAB International, Wallingford, pp. 47-66.

Coleman, D.C., Odum, E.P., Crossley, D.A. Jr, 1992. Soil biology, soil ecology, and global change. Biol. Fertil. Soils 14, 104-111.

Cornelissen, J.H., Van Bodegom, P.M., Aerts, R., Callaghan, T.V., Van Logtestijn, R.S., Alatalo, J., Chapin, F.S., Gerdol, R., Gudmundsson, J., Gwynn-Jones, D., Hartley, A.E., Hik, D.S., Hofgaard, A., Jónsdóttir, I.S., Karlsson, S., Klein, J.A., Laundre, J., Magnusson, B., Michelsen, A., Molau, U., Onipchenko, V.G., Quested, H.M., Sandvik, S.M., Schmidt, I.K., Shaver, G.R., Solheim, B., Soudzilovskaia, N.A., Stenström, A., Tolvanen, A., Totland, Ø., Wada, N., Welker, J.M., Zhao, X., 2007. Global negative vegetation feedback to climate warming responses of leaf litter decomposition rates in cold biomes. Ecol. Lett. 10, 619-627.

Cox, P.M., Betts, R.A., Jones, C.D., Spall, S.A., Totterdell, I.J., 2000. Acceleration of global warming due to carbon-cycle feedbacks in a coupled climate model. Nature 408, 184-187. 
De Nicola, C., Zanella, A., Testi, A., Fanelli, G., Pignatti, S., 2014. Humus forms in a Mediterranean area (Castelporziano Reserve, Rome, Italy): classification, functioning and organic carbon storage. Geoderma 235/236, 90-99.

Dimbleby, G.W., 1962. The development of British heathlands and their soils. Oxford For. Mem. 23, $1-50$.

Eilers, K.G., Debenport, S., Anderson, S., Fierer, N., 2012. Digging deeper to find unique microbial communities: the strong effect of depth on the structure of bacterial and archaeal communities in soil. Soil Biol. Biochem. 50, 58-65.

Elliott, E.T., Coleman, D.C., 1988. Let the soil work for us. Ecol. Bull. 39, 23-32.

Emmer, I.M., 1994. Humus form characteristics in relation to undergrowth vegetation in a Pinus sylvestris forest. Acta Oecol. 15, 677-687.

Emmer, I.M., 1995. Humus form development and succession of dwarf shrub vegetation in grass dominated primary Pinus sylvestris forests. Ann. Sci. For. 52, 561-571.

Fierer, N., Bradford, M.A., Jackson, R.B., 2007. Toward an ecological classification of soil bacteria. Ecology 88, 1354-1364.

Galvan, P., Ponge, J.F., Chersich, S., Zanella, A., 2008. Humus components and soil biogenic structures in Norway spruce ecosystems. Soil Sci. Soc. Am. J. 72, 548-557.

Géhu J.M., 1980. La phytosociologie d'aujourd'hui. Méthodes et orientations. Not. Fitosoc. 16, 1-16.

Géhu, J.M., 1991. L'analyse symphytosociologique et géosymphytosociologique de l'espace: théorie et méthodologie. Coll. Phytosoc. 17, 12-46.

Géhu, J.M., 1992. Réflexions sur les fondements syntaxonomiques nécessaires à une synthèse des végétations à l'échelle du continent européen et esquisse d'un synsystème dans l'optique de la phytosociologie Braun-Blanqueto-Tüxenienne: ébauche de synsystème pour la France. Annali Bot. 1, 131-147.

Géhu, J.M., 1996. Epistémologie de la territorialité en phytosociologie. Giorn. Bot. Ital. 130, 189-199.

Géhu, J.M., Rivas-Martinez, S., 1981. Notions fondamentales de Phytosociologie. In: Dierschke, H. (ed.), Syntaxonomie. Cramer, Vaduz, pp. 5-33.

Gillet, F., de Foucault, B. (de), Julve Ph, P., 1991. La phytosociologie synusiale intégrée: objets et concepts. Candollea, 46, 315-340.

Gillet, F., 2000. La Phytosociologie synusiale intégrée.Synusiale Intégrée: Guide Méthodologique. Université de Neuchâtel, Institut de Botanique, Neuchâtel.

Graefe, U., Beylich, A., 2006. Humus forms as tool for upscaling soil biodiversity data to landscape level? Mitt. Deutschen Bodenk. Gesellsch. 108, 6-7. 
Ibáñez, J.J., Krasilnikov, P.V., Saldaña, A., 2012. Archive and refugia of soil organisms: applying a pedodiversity framework for the conservation of biological and nonbiological heritages. J. Appl. Ecol. 49, 1267-1277.

Klinge, H., 1965. 1995. Podzol soils in the Amazon basin. J. Soil Sci. 16, 95-103.

Klinka, K., Green, R.N., Trowbridge, R.L., Lowe, L.E., 1981. Taxonomic Classification of Humus Forms in Ecosystems of British Columbia, First Approximation. Province of British Columbia, Ministry of Forests, Victoria. https://www.for.gov.bc.ca/hfd/pubs/Docs/Mr/Lmr/Lmr008.pdf (Accessed 30 August 2017).

Kounda-Kiki, C., Ponge, J.F., Mora, P., Sarthou, C., 2008. Humus profiles and successional development in a rock savanna (Nouragues inselberg, French Guiana): a micromorphological approach infers fire as a disturbance event. Pedobiologia 52, 85-95.

Kumada, 1987. Chemistry of Soil Organic Matter. Elsevier, Amsterdam.

Labaz, B., Galka, B., Bogacz, A., Waroszewski, J., Kabala, C., 2014. Factors influencing humus forms and forest litter properties in the mid-mountains under temperate climate of southwestern Poland. Geoderma 230-231.

Lalanne, A., Bardat, J., Lalanne-Amara, F., Gautrot, T., Ponge, J.F., 2008. Opposite responses of vascular plant and moss communities to changes in humus form, as expressed by the Humus Index. J. Veg. Sci. 19, 645-652.

Lavelle, P., 2002. Functional domains in soils. Ecol. Res. 17, 441-450.

MacArthur, R., Wilson, E.O., 1967. The Theory of Island Biogeography. Princeton University Press, Princeton.

Macfadyen, A., 1963. The contribution of the microfauna to total soil meatabolism. In: Doeksen, J., Van der Drift, J. (Eds.), Soil Organisms. North Holland Publishing Company, Amsterdam, pp. 317.

Marinissen, J.C.Y., Van den Bosch, F., 1992. Colonization of new habitats by earthworms. Oecologia 91, 371-376.

Martin, A., 1991. Short- and long-term effects of the endogeic earthworm Millsonia anomala (Omodeo) (Megascolecidae, Oligochaeta) of tropical savannas, on soil organic matter. Biol. Fertil. Soils 11, 234-238.

Moore, J.C., Hunt, H.W., 1988. Resource compartmentation and the stability of real ecosystems. Nature 333, 261-263.

Niemelä, J., Haila, Y., Punttila, P., 1996. The importance of small-scale heterogeneity in boreal forests: variation in diversity in forest-floor invertebrates across the succession gradient. Ecography 19, 352-368.

Odum, E.P., 1969. The strategy of ecosystem development. Science 164, 262-270. 
Pinzari, F., Dell'Abate, M.T., Benedetti, A., Dazzi, C., 2001. Forest humus forms as potential indicators of soil carbon storage in Mediterranean environments. Can. J. Soil Sci. 81, 553-560.

Ponge, J.F., Chevalier, R., 2006. Humus Index as an indicator of forest stand and soil properties. For. Ecol. Manag. 233, 165-175.

Ponge, J.F., Chevalier, R., Loussot, P., 2002. Humus Index: an integrated tool for the assessment of forest floor and topsoil properties. Soil Sci. Soc. Am. J. 66, 1996-2001.

Ponge, J.F., Jabiol, B., Gégout, J.C., 2011. Geology and climate conditions affect more humus forms than forest canopies at large scale in temperate forests. Geoderma 162, 187-195.

Ponge, J.F., 1991a. Succession of fungi and fauna during decomposition of needles in a small area of Scots pine litter. Plant Soil 138, 99-113.

Ponge, J.F., 1991b. Food resources and diets of soil animals in a small area of Scots pine litter. Geoderma 49, 33-62.

Ponge, J.F., 1999. Interaction between soil fauna and their environment. In: Rastin, N., Bauhus, J. (Eds.), Going Underground: Ecological Studies in Forest Soils. Resarch Signpost, Trivandrum, pp. 45-76.

Ponge, J.F., 2000. Vertical distribution of Collembola (Hexapoda) and their food resources in organic horizons of beech forests. Biol. Fertil. Soils 32, 508-522.

Ponge, J.F., 2003. Humus forms in terrestrial ecosystems: a framework to biodiversity. Soil Biol. Biochem. 35, 935-945.

Ponge, J.F., 2005. Emergent properties from organisms to ecosystems: towards a realistic approach. Biol. Rev. 80, 403-411.

Ponge, J.F., 2013. Plant-soil feedbacks mediated by humus forms. Soil Biol. Biochem. 57, 1048-1060.

Ponge, J.F., 2015. The soil as an ecosystem. Biol. Fertil. Soils 51, 645-648.

Royo, A.A., Carson Walter, P., 2006. On the formation of dense understory layers in forests worldwide: consequences and implications for forest dynamics, biodiversity, and succession. Can. J. For. Res. 36, 1345-1362.

Stevenson, F.J., 1994. Humus Chemistry: Genesis, Composition, Reactions, $2^{\text {nd }}$ ed. John Wiley and Sons, Hoboken.

Tagger, S., Périssol, C., Criquet, S., Aubert, G., Neville, P., Le Petit, J., Toutain, F., 2008. Characterization of an amphimull under Mediterranean evergreen oak forest (Quercus ilex): micromorphological and biodynamic descriptions. Can. J. For. Res. 38, 268-277.

Takeda, H., 1998. Decomposition processes of litter along a latitudinal gradient. In: Sassa, K. (Ed.), Environmental Forest Science. Kluwer, London Dordrecht, pp. 197-206.

Targulian, V.O., Krasilnikov, P.V., 2007. Soil system and pedogenic processes: self-organization,time scales, and environmental significance. Catena 71, 373-381. 
Topoliantz, S., Ponge, J.F., Viaux, P., 2000. Earthworm and enchytraeid activity under different arable farming systems, as exemplified by biogenic structures. Plant Soil 225, 39-51.

Ulrich, B., 1986. Natural and anthropogenic components of soil acidification. Z. Pflanzenernähr. Bodenk. 149, 702-717.

Van der Maarel, E., 2005. Vegetation Ecology. Blackwell Publishing, Oxford.

Wang, T.S.C., Huang, P.M., Chou, C.H., Chen, J.H., 1986. The role of soil minerals in the abiotic polymerization of phenolic compounds and formation of humic substances. In: Huang, P.M., Schnitzer, M. (Eds.), Interactions of Soil Minerals Soil Minerals with Natural Organics Natural Organics and Microbes. Soil Science Society of America, Madison, pp. 51-281.

Willis, K.J., Braun, M., Sümegi, P., Tóth, A., 1997. Does soil change cause vegetation change or vice versa? A temporal perspective from Hungary. Ecology 78, 740-750.

Zanella, A., Tomasi, M., De Siena, C., Frizzera, L., Jabiol, B., Nicolini, G., Sartori, G., Calabrese, M.S., Mancabelli, A., Nardi, S., Pizzeghello, D., Odasso, M., 2001. Humus Forestali. Centro di Ecologia, Alpina, Trento.

Zanella, A., Jabiol, B., Ponge, J.F., Sartori, G., De Waal, R., Van Delft, B., Graefe, U., Cools, N., Katzensteiner, K., Hager, H., Englisch, M., Brêthes, A., 2009. Toward a European humus forms reference base. Stud. Trent. Sci. Nat. 85, 145-151.

Zanella, A., Jabiol, B., Ponge, J.F., Sartori, G., De Waal, R., Van Delft, B., Graefe, U., Cools, N., Katzensteiner, K., Hager, H., Englisch, M., 2011. A European morphofunctional classification of humus forms. Geoderma 164, 138-145. 


\section{Figure captions}

Fig. 1. Two examples of terrestrial humus forms belonging to different humus systems (see Humusica, article 5 for diagnostic criteria): a) Mor humus system (Humimor humus form, accumulation of humified organic matter with an abrupt transition to the rocky substrate) in a heath with Calluna vulgaris, Erica cinerea and Ulex europaeus, on granitic parent material near Crozon (Armorican Massif, Brest, France); b) Amphi humus system (Eumacroamphi humus form, with a thick humified organic layer overlying a thick macro-aggregated mineralorganic horizon) in a Pinus nigra forest with a field layer of Erica herbacea, on calcareous parent material near Calalzo (Alps, Belluno, Italy).

Fig. 2. Two common humus systems in West-European forests: a) oak-hornbeam forest with a Mull humus system (no accumulation of organic horizons except nOL and vOL, Mesomull humus form); b) a birch-oak forest with a Moder humus system (accumulation at the soil surface of organic horizons, $\mathrm{OL}, \mathrm{OF}$ and $\mathrm{OH}$, Eumoder humus form).

Fig. 3. Soil animals: a) enchytraeids (white small annelids) among macroarthropods, sampled in a Moder in Fontainebleau forest (France); b) an enchytraeid in the $\mathrm{OH}$ horizon of a beech forest in the Dolomites (San Vito di Cadore, Italy), note that the dark humified organic matter in powder is an accumulation of faeces of these tiny potworms (visible by transparency across the body wall).

Fig. 4. Crusto humus systems: a) cryptogamic vegetation covering a plate of schist (acid metamorphic rock) near the biological station of Paimpont (French Brittany, France); b) the soil profile of a Crusto humus system, with a thin $(<1 \mathrm{~cm})$ organic-mineral cruOA horizon lying directly on slightly altered rock.

Fig. 5. Biological soil aggregates: a) anecic earthworm aggregates (mineral-organic casts) deposited at the soil surface in a grassland from the campus of the University of Paris 11 (Orsay, France); b) arthropod (millipede) mineral-organic droppings deposited among pine needles in a Pinus halepensis seaside forest (Oropesa del Mar, Spain).

Fig. 6. Evolution: Imaginary representation of the cyclic process of bio-degradation and biocomplexification, which corresponds to a succession of organism generations. For acceding to a future space-time structure, an organism must decompose and pass through a neck, like sand grains in an hourglass; the thin units of information have the dimensions of small organic molecules (parts of DNA and other molecules). A succession of necks, may be necessary to build the Darwinian tree of evolution.

Fig. 7. Organic horizons obliquely cut through a beech forest acid soil (Podzol), showing stages of litter ageing along a humus profile, from left to right OLn (fresh litter) then OLv (verbleicht = bleached), then OF (fragmented), then $\mathrm{OH}$ (homogeneous, well-humified, made of small particles of dark organic matter) and finally grey-black humic matter impregnating the sand in the underneath mineral horizon (E horizon). Note that during the preparation of the profile some intact beech leaves have been fortuitously carried by wind down to "deeper" parts of the profile (right side of the picture), while belonging only to the superficial litter (left side). 
Fig. 8. Aspect can influence the development of different humus systems: in Alpine mountain ecosystems (Val di Non, Trento, Italy) at the altitudinal level where deciduous (beech) forests let the place to coniferous (spruce) forests, north aspect is favourable to Moder, east aspect to Amphi and south aspect to Mull humus systems.

Fig. 9. Humus systems as "attractive holes" in an imaginary ecological landscape: like golf balls, natural ecosystems move across an evolutionary surface and fall in holes in which requirements (ecological, physiological) of biotic communities fit the best with abiotic conditions (climate, geology), in dynamic equilibrium during a more or less short historical moment.

Fig. 10. A mosaic of two Amphi humus forms at the edge of an Alpine forest (Pinus sylvestris and Juniperus communis) on a rendzic Leptosol (WRB) overlying calcareous bedrock: a thick $\mathrm{OH}$ horizon (Pachyamphi) is observed under Erica carnea heath cover (1) while a much thinner $\mathrm{OH}$ horizon (Eumesoamphi) is observed under Sesleria albicans, Carex humilis, Calamagrostis villosa grass cover (2).

Fig. 11. Imaginary boxes enclosing ecosystems in which humus systems and forms are investigated at various scales. Box 1 encloses three different ecosystems: 1a, Rhododendron ferrugineum and Vaccinium myrtillus Alpine shrubby areas; 1c, Avenella flexuosa and Nardus stricta Alpine grazing areas; $1 \mathrm{~b}$, mosaic of the two preceding communities. Box 2 encloses a complex forest ecosystem dominated by Larix decidua (2a), with Alnus viridis in avalanche channels (2b). It is possible to assign a compound humus form name to each box.

Fig. 12. Imaginary boxes enclosing ecosystems we can investigate at the level of humus systems and forms. In Box 1, a single humus form (here Mull) is covering more than $70 \%$ of the whole area, giving its name to the box. In Box 2, enlarging the imaginary box, two humus forms co-exist in the same box. The name of the humus form covering Box 2 is then composed of two names, separated by a dash, the minor component ( $>30 \%$ ) being followed by the major component $(\leq 70 \%)$. In Box 3 the percent cover of both humus forms is inverted, the composite name is also inverted. In Box 4 the dominant humus form makes more than $70 \%$ of the whole surface, giving its name to Box 4 .

Fig. 13. Examples of imaginary boxes enclosing humipedons: a) Moder system in a coniferous mixed forest on a Podzolic soil, generated on a poor in base quartz-phylladic rock; b) Humimor in an Alpine grazing area, under a thick shrub of Rhododendron ferrugineum, on a Podzol over a base-poor granitic rock; c) Mesomull in a Mediterranean forest of Pinus halepensis and Quercus coccifera, in a Cambisol on calcareous rock; d) left: very organic biomacro Agro Mull in a tilled area, under corn crop; right: Eumull under meadow. Roots and anecic earthworms form a A horizon, resistant to erosion, which occupies the top part of the cube. Field discussion during the Congress of the European Society of Soil Conservation in Cluj-Napoca (Rumania, 2016). 
a

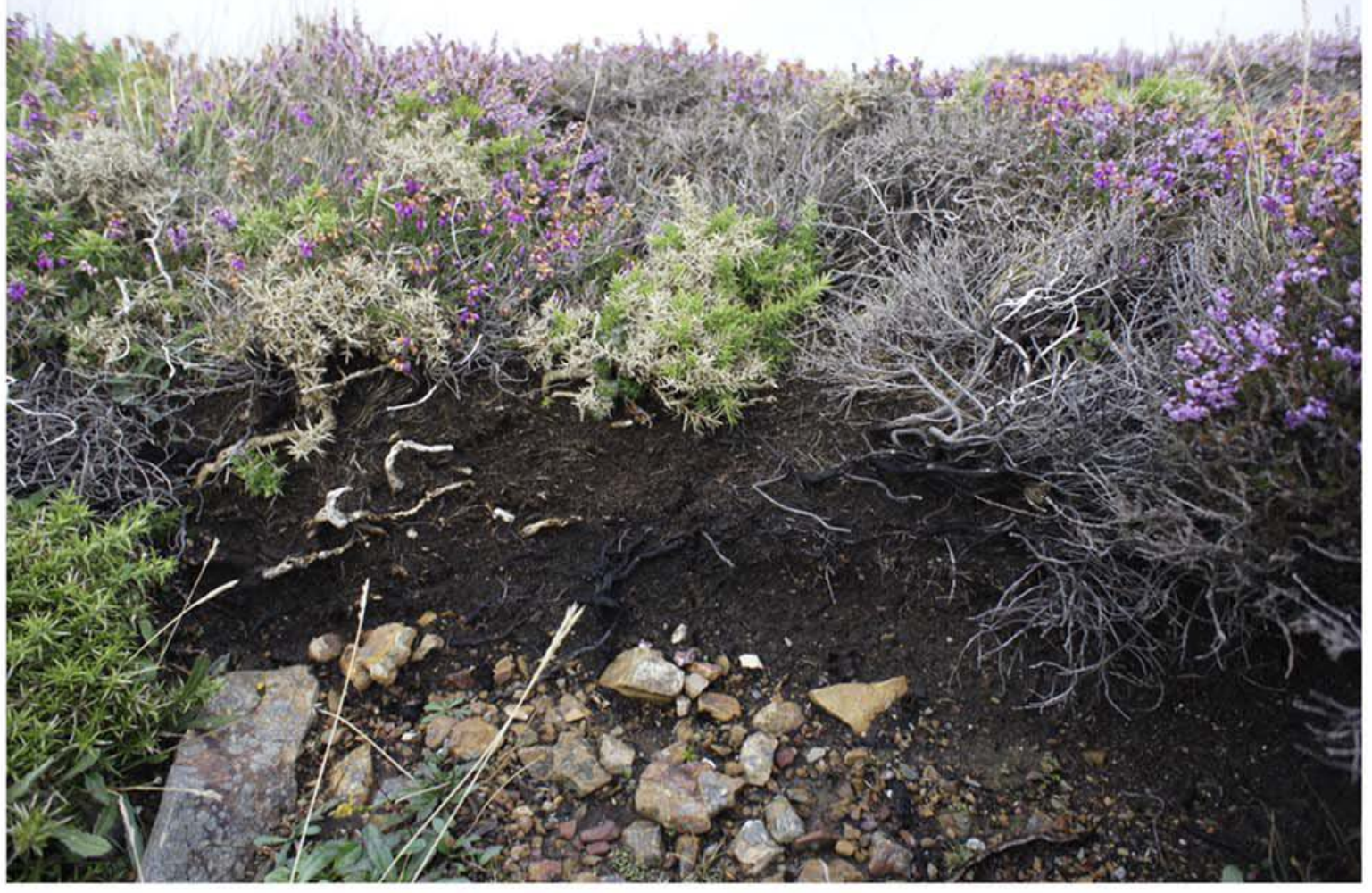

b

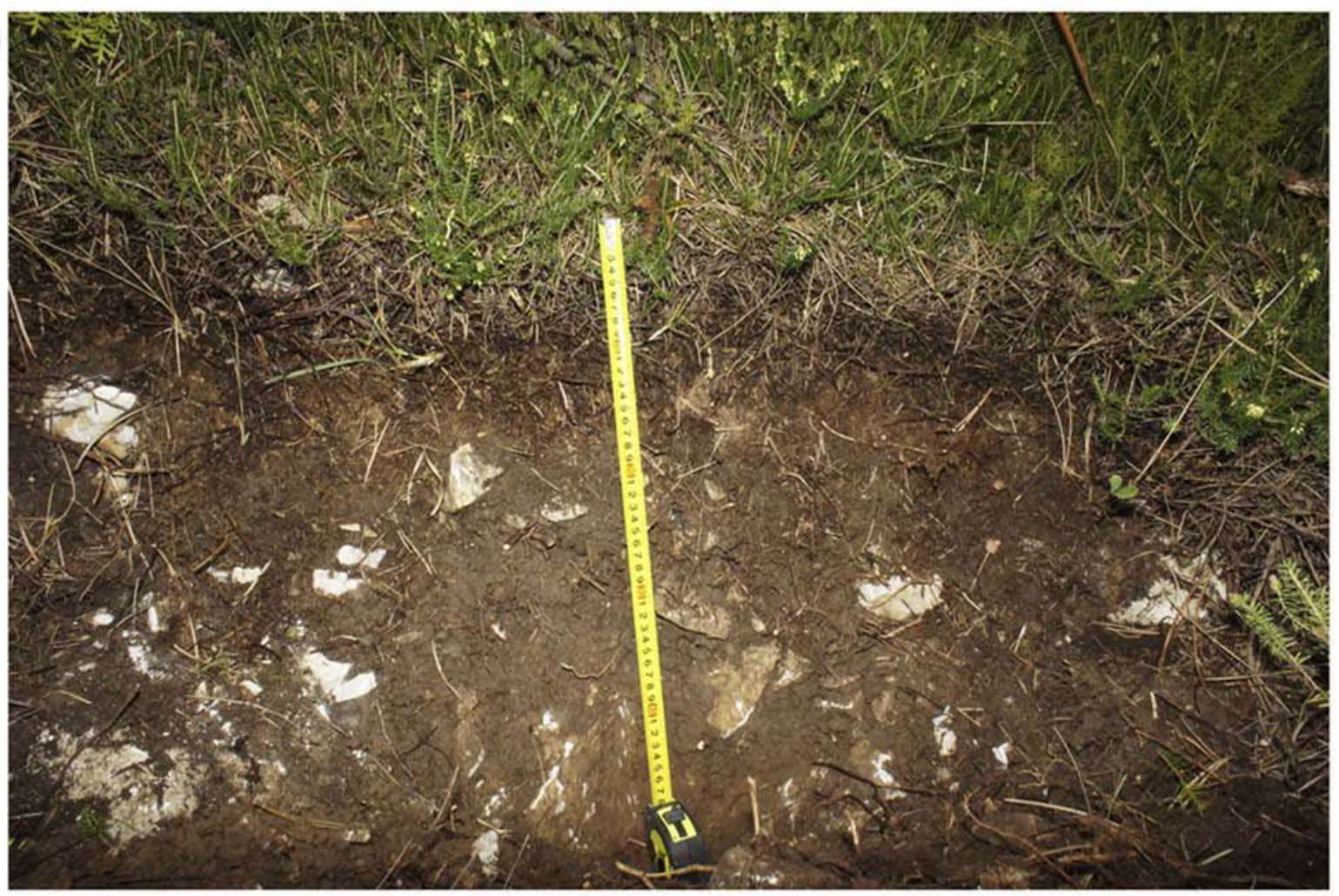

Fig. 1 

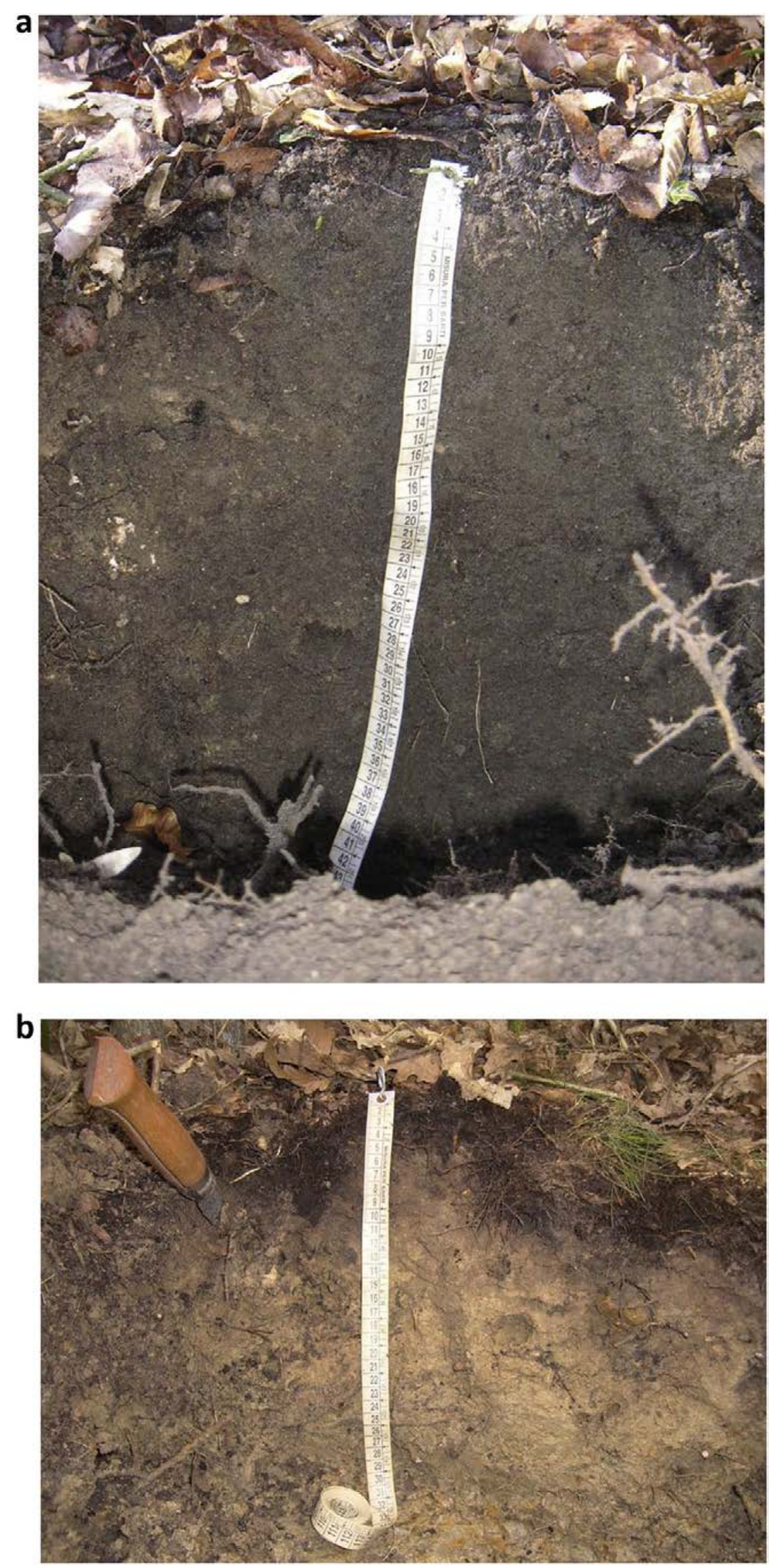

Fig. 2 


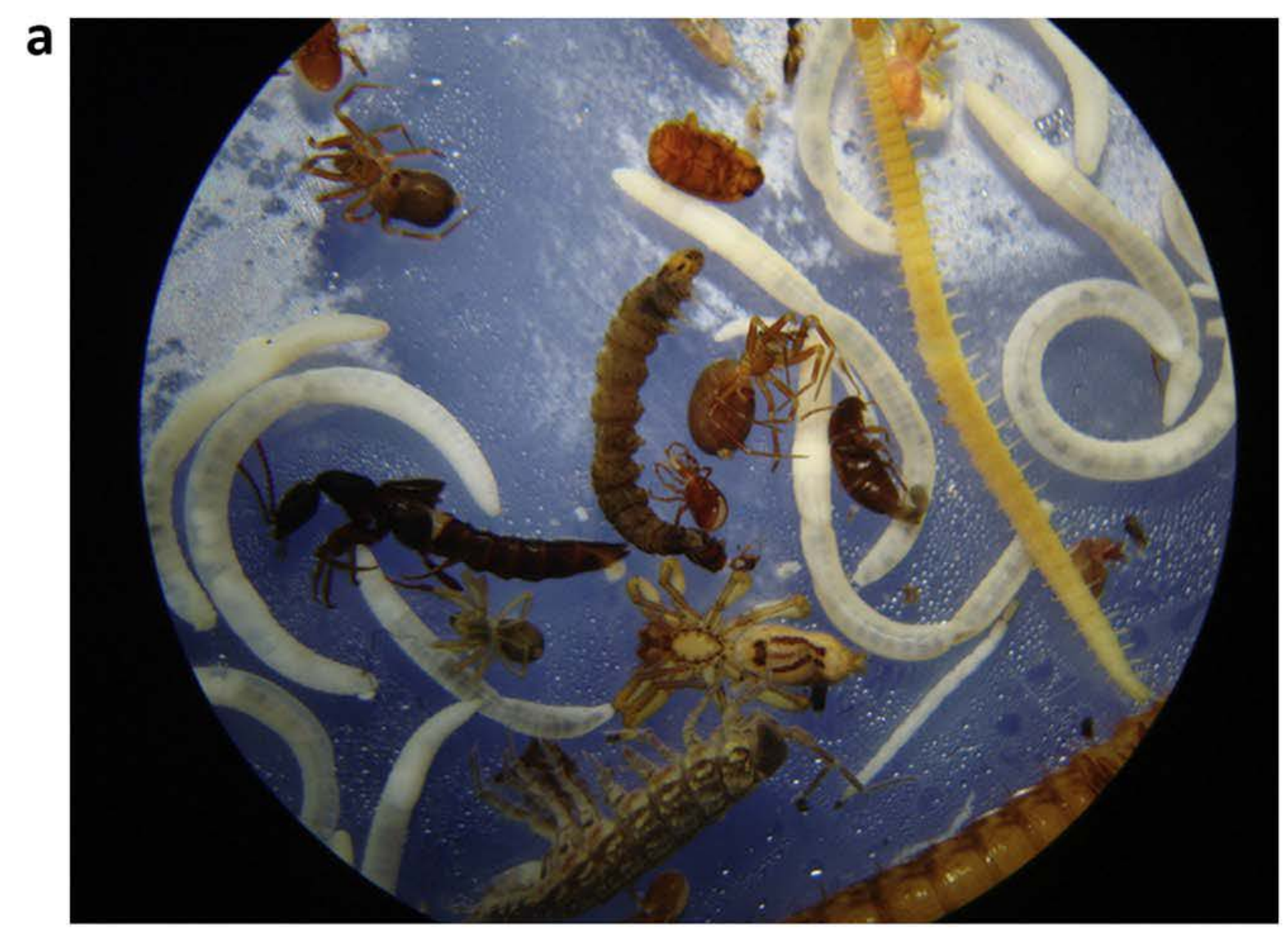

b

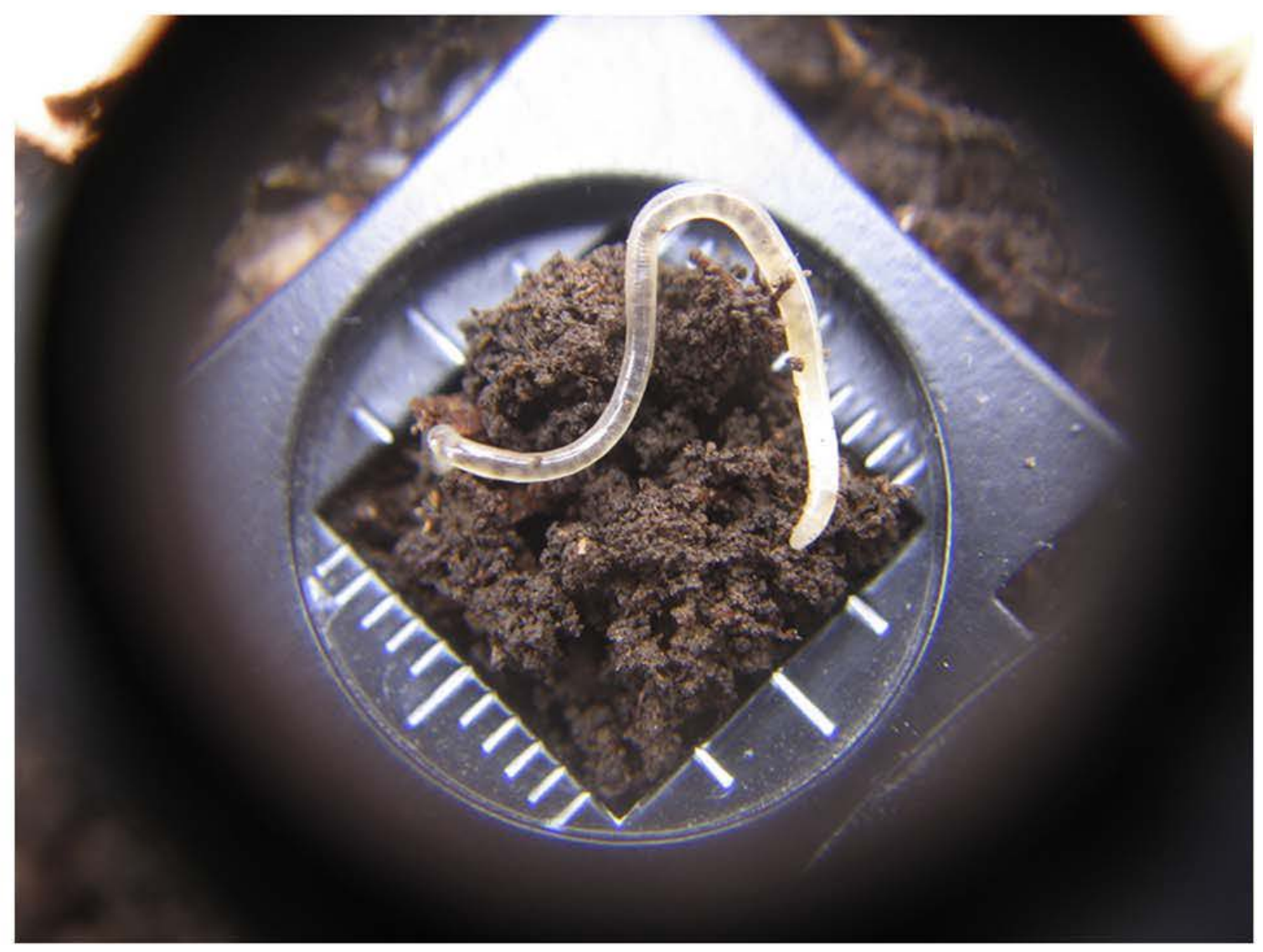

Fig. 3 

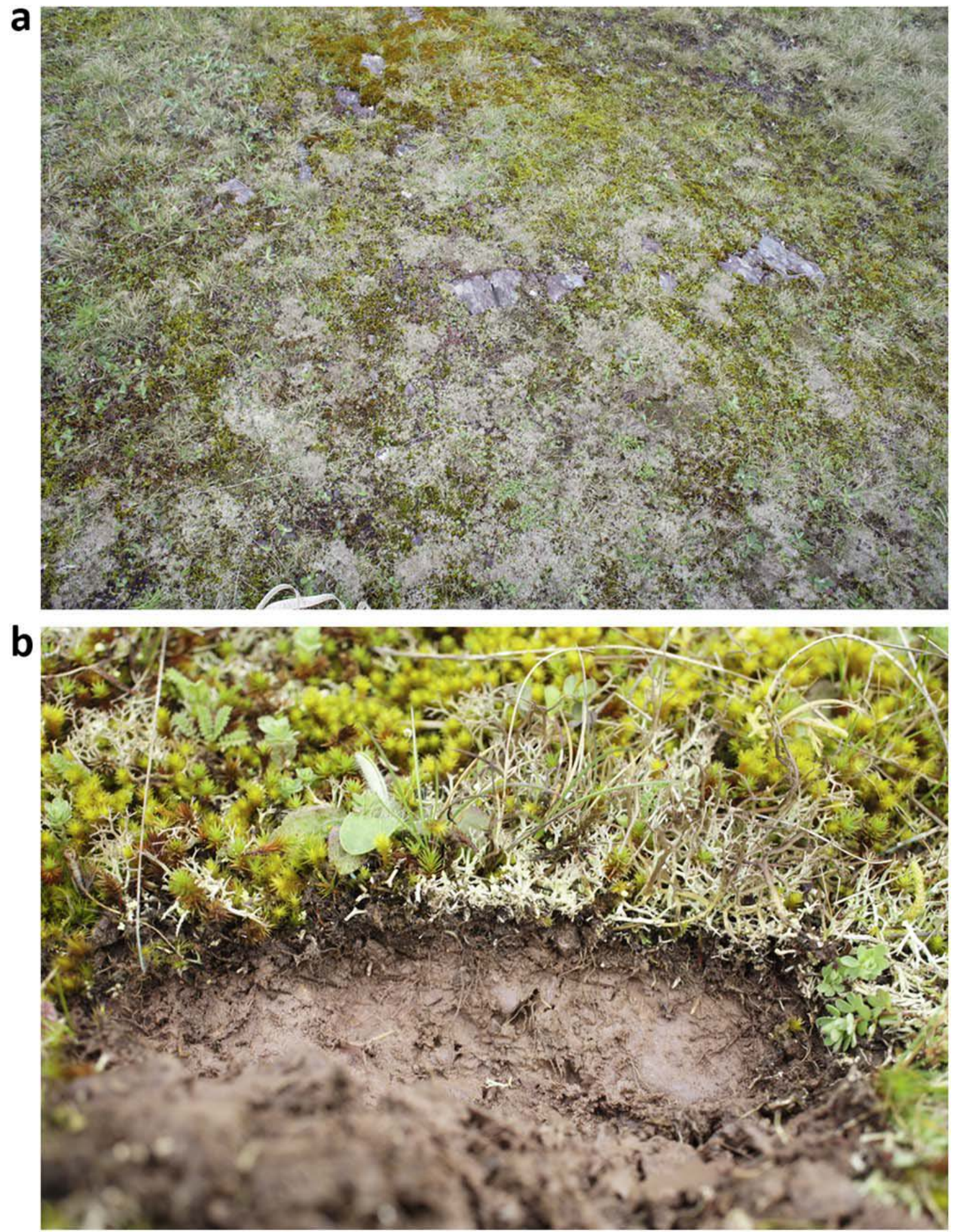

Fig. 4 


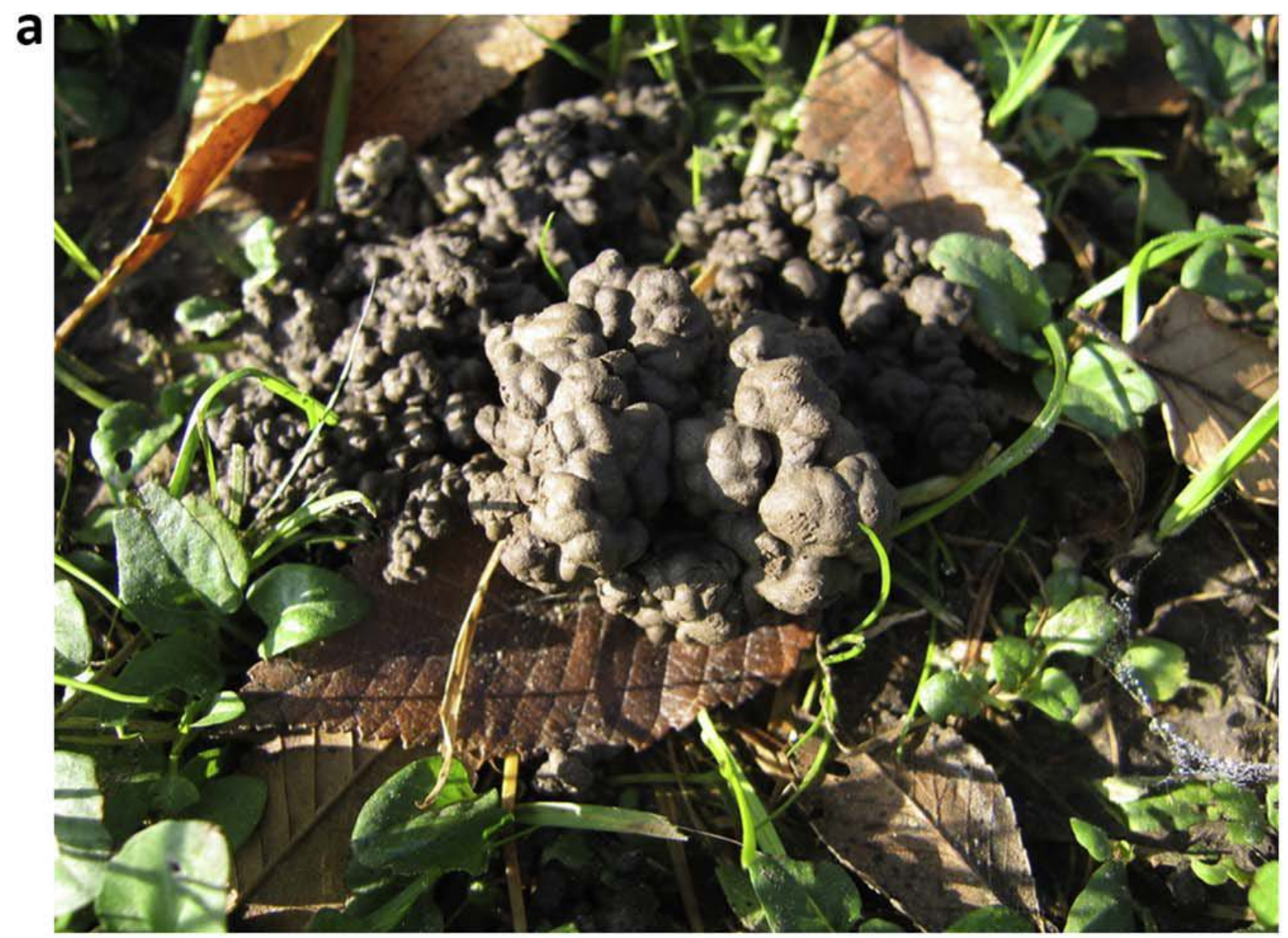

b

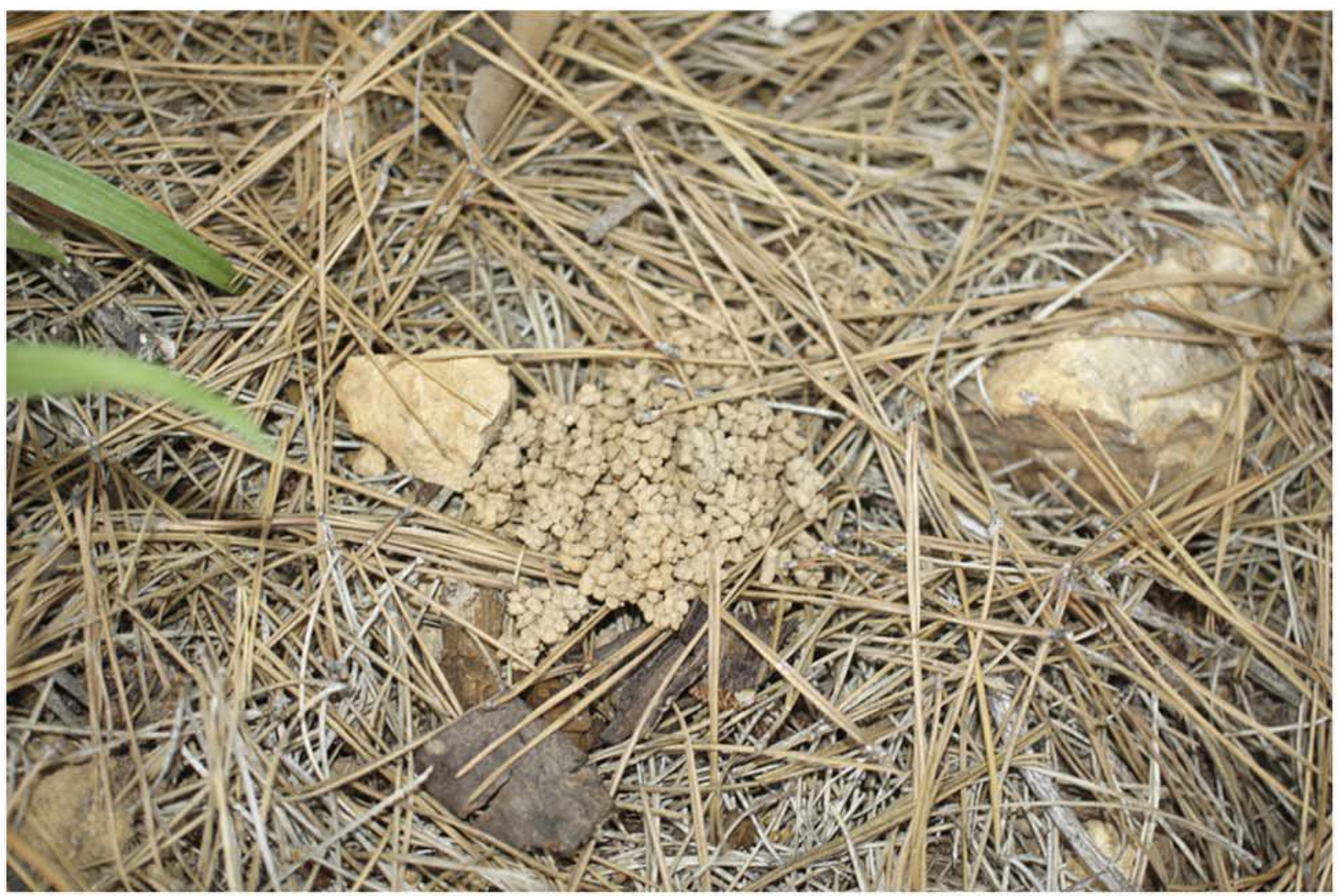

Fig. 5 


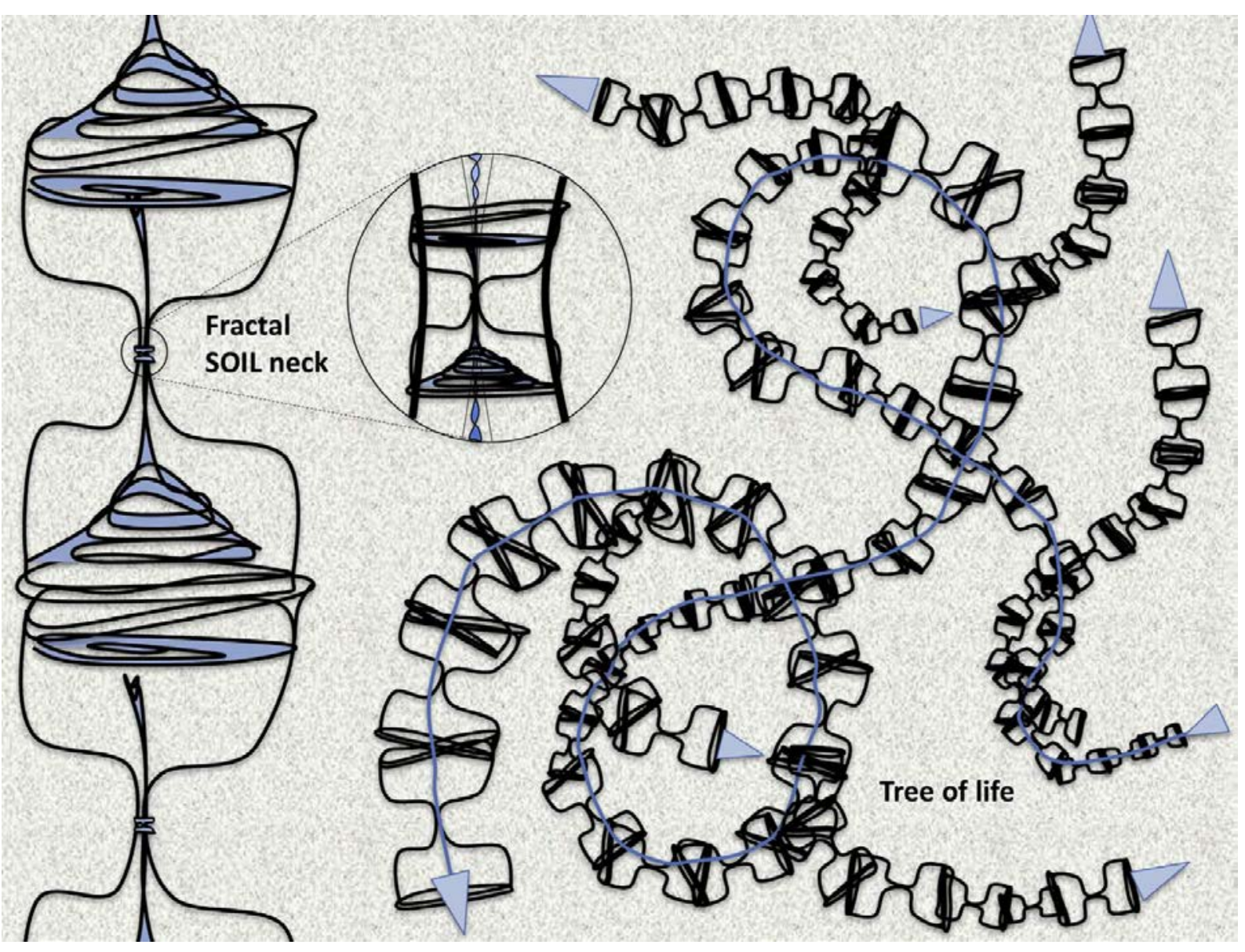

Fig. 6 


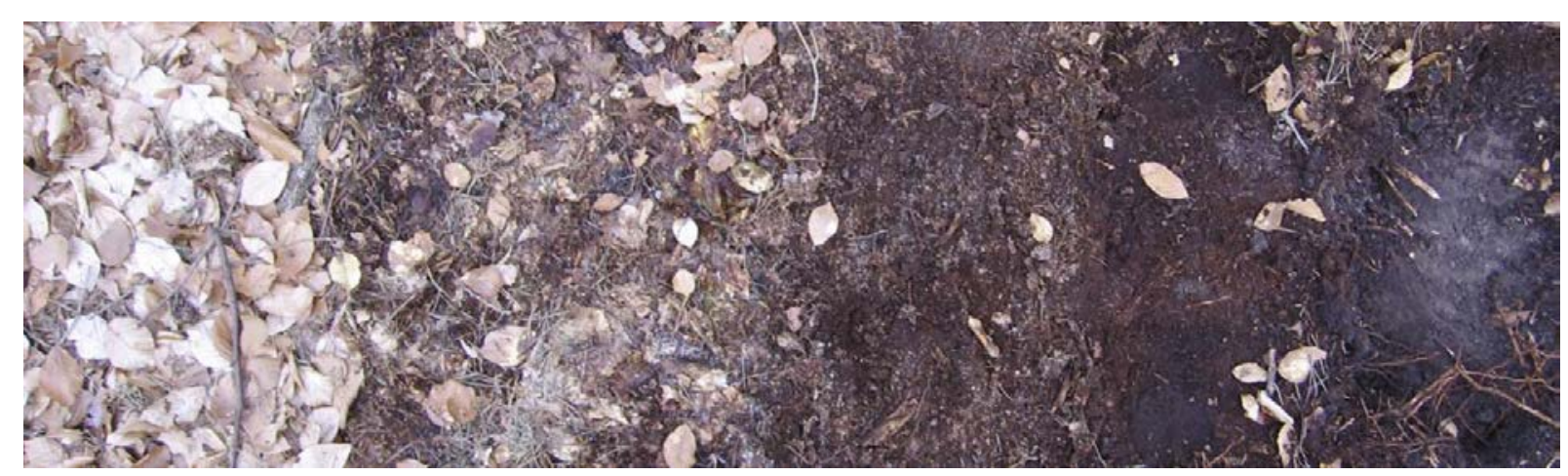

Fig. 7 


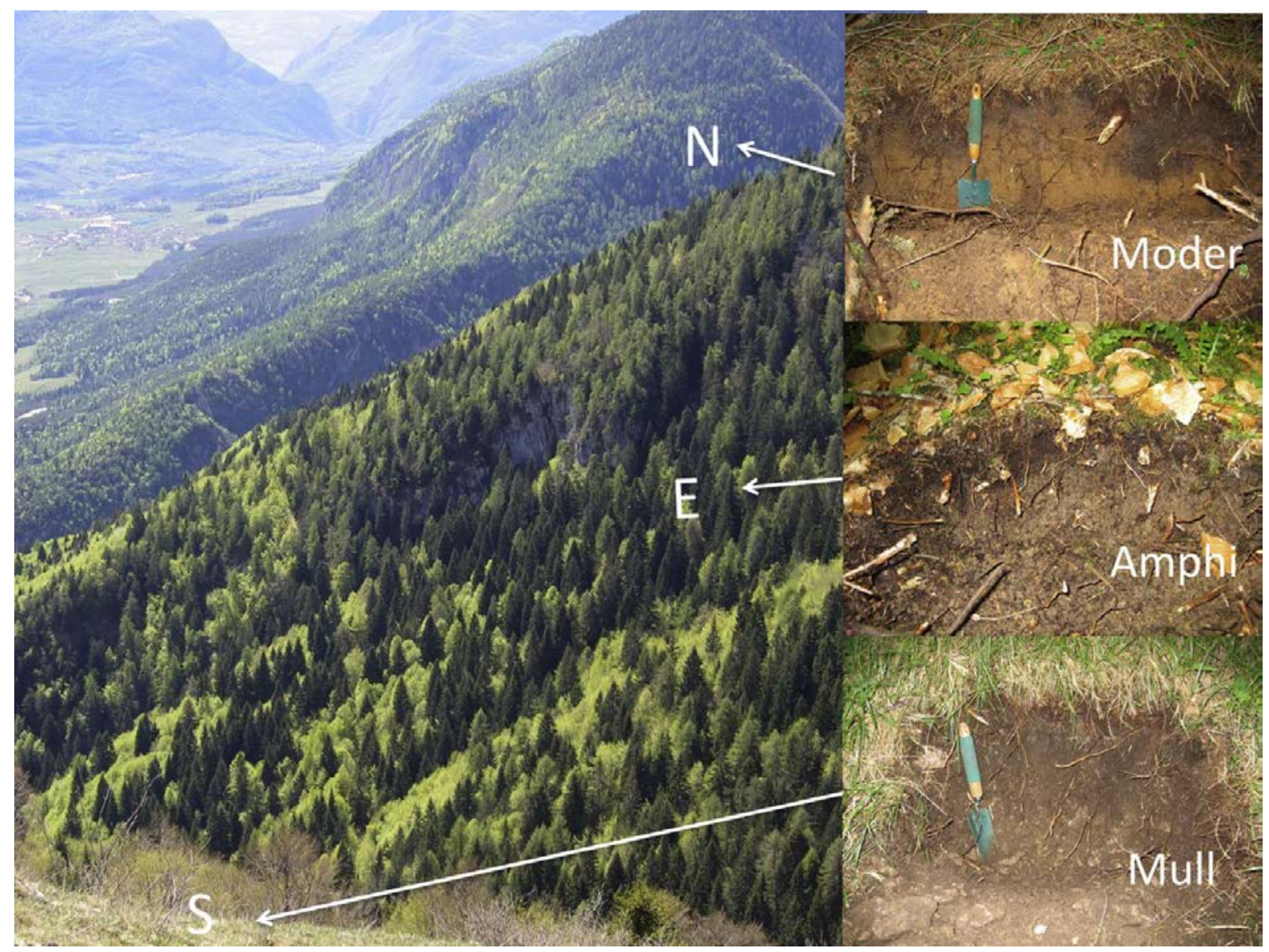

Fig. 8 


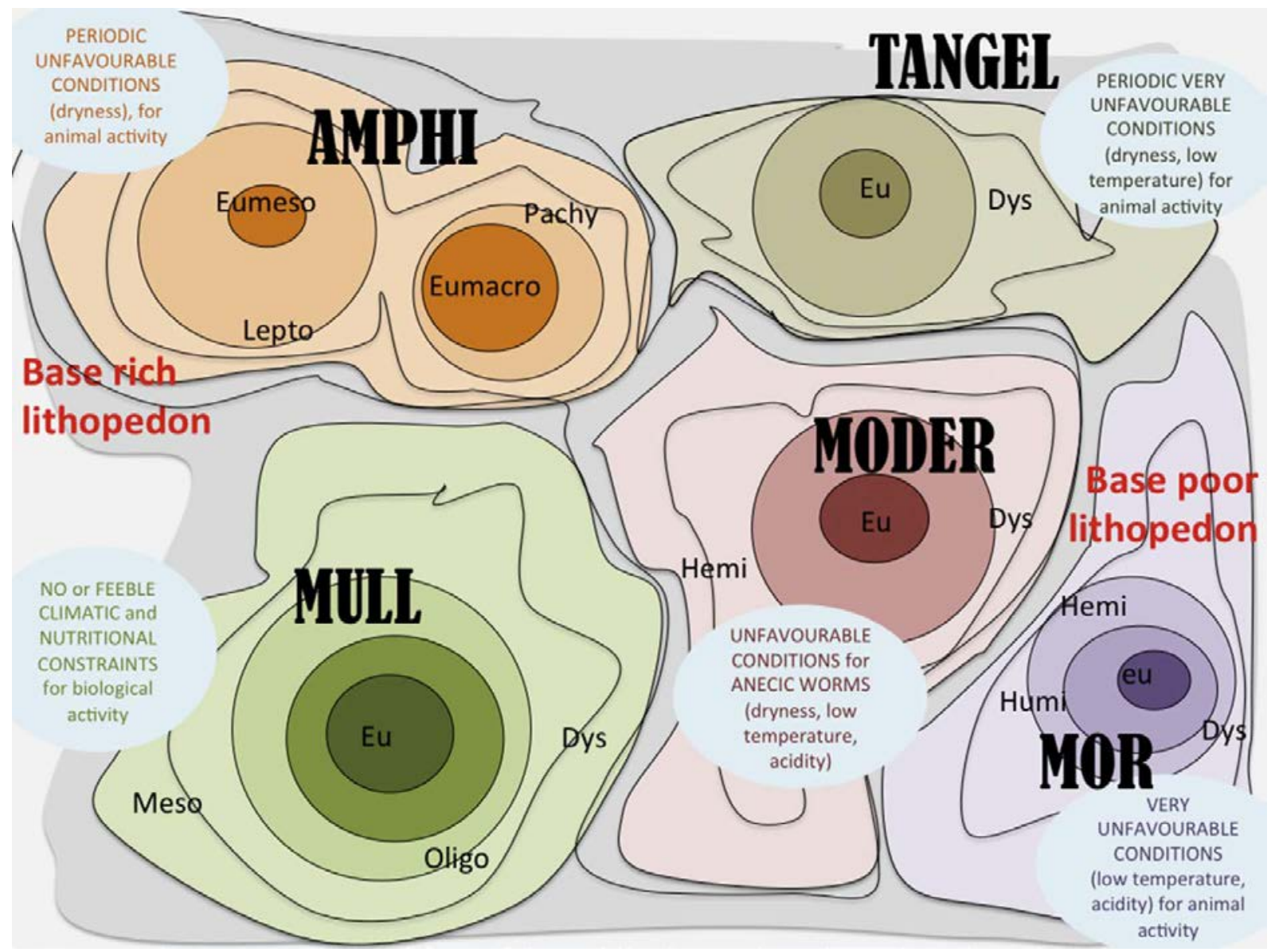

Fig. 9 


\section{0}

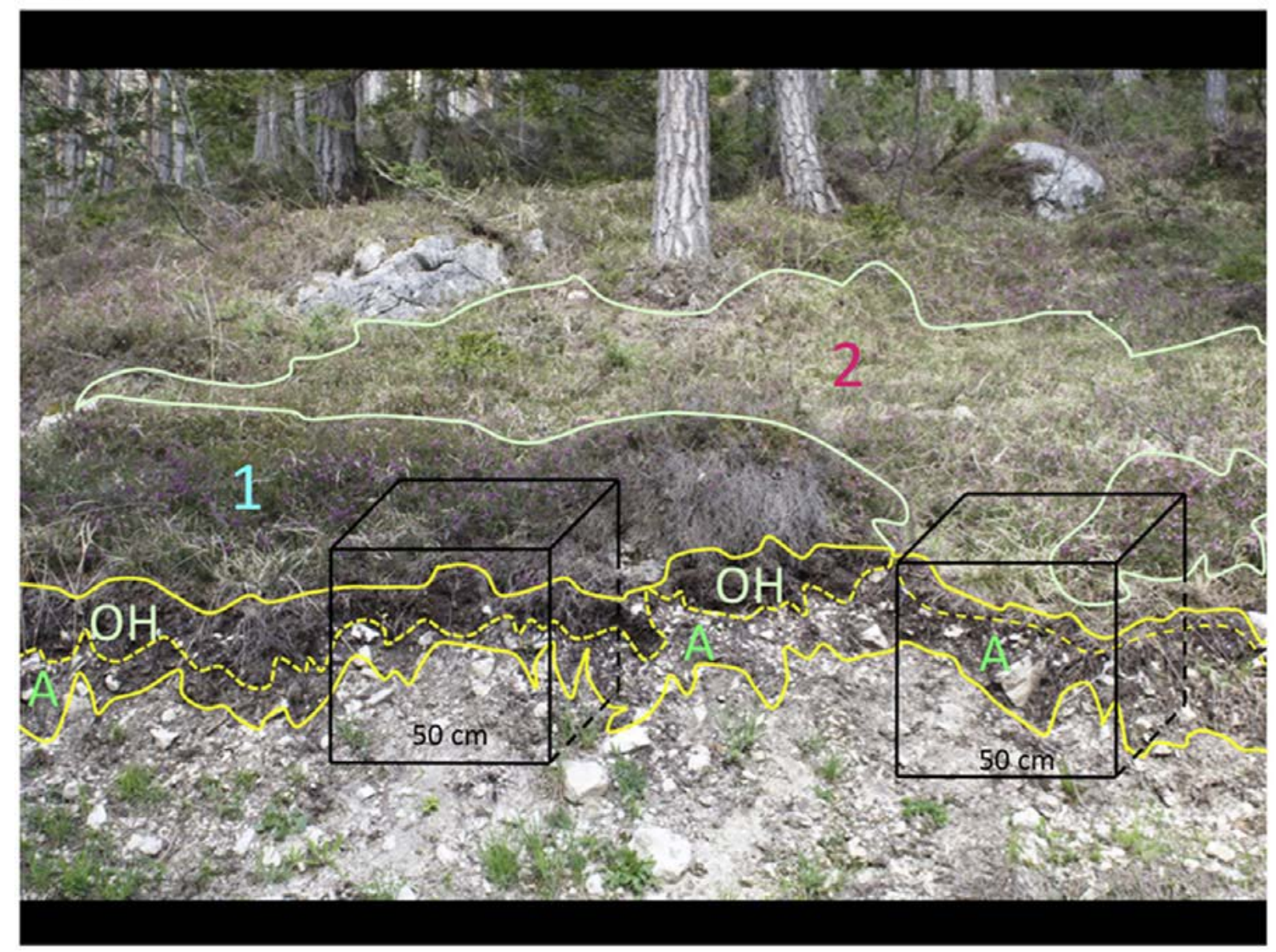

Fig. 10 


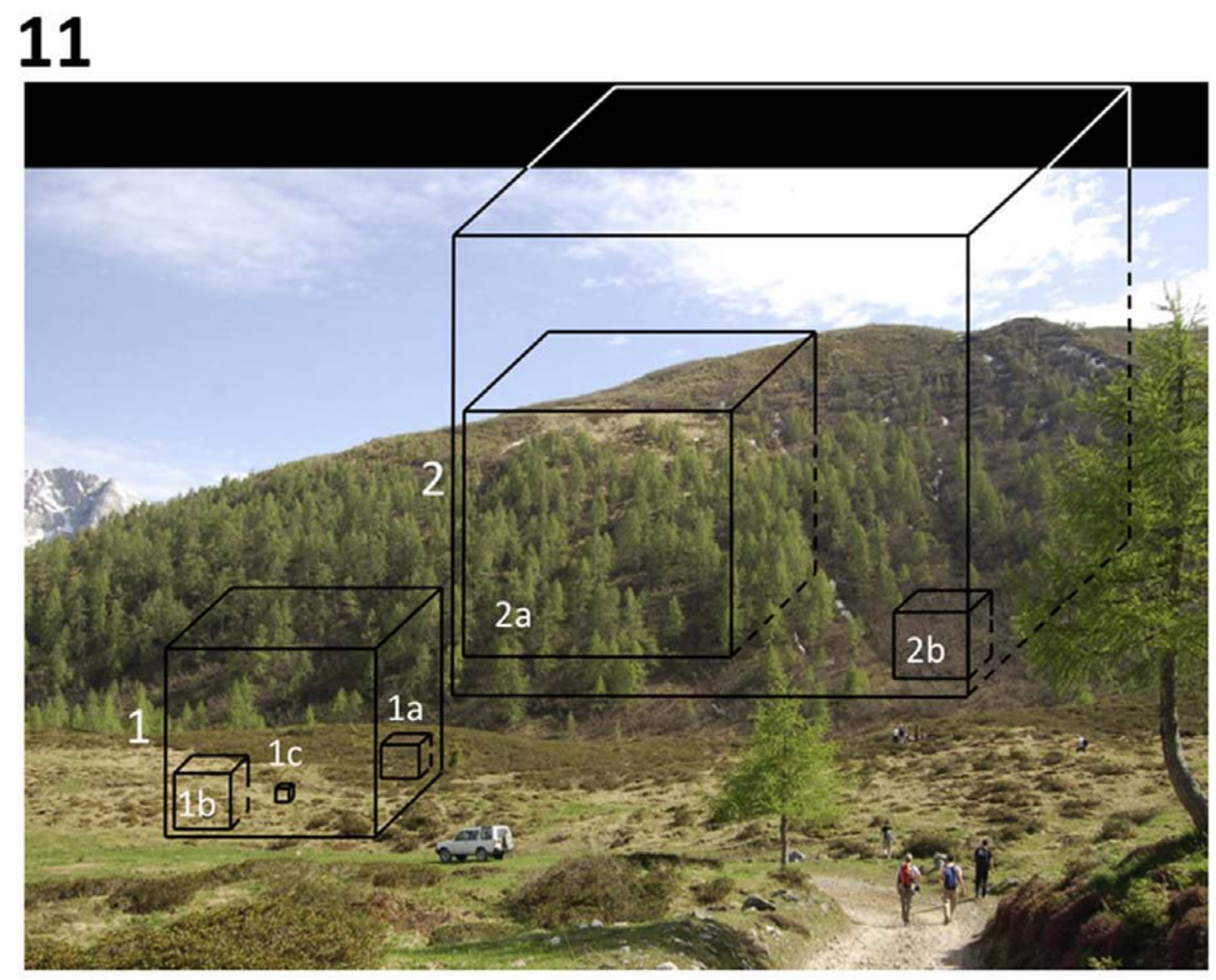

Fig. 11 


\section{2}

Example: $A=$ Mull; $B=$ Moder

In box $1, A$ covers $>70 \%$ of the surface, name: Mull

In box $2, A$ covers more than $B$, but $70 \%$ or less of the surface, name: Moder-Mull In box $3, B$ covers more than $A$, but $70 \%$ or less of the surface, name: Mull-Moder In box $4, B$ covers $>70 \%$ of the surface, name: Moder

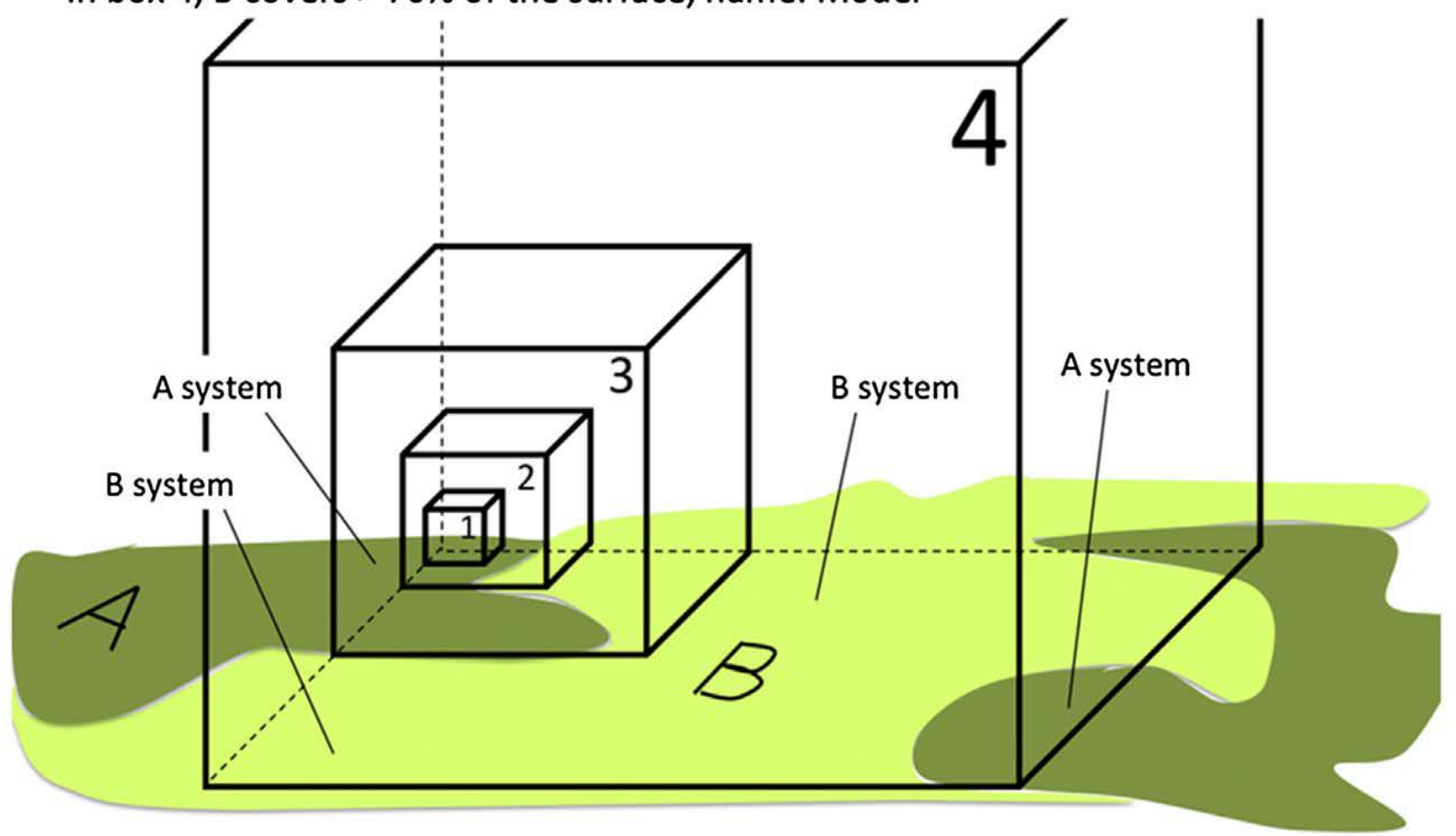

Fig. 12 
a

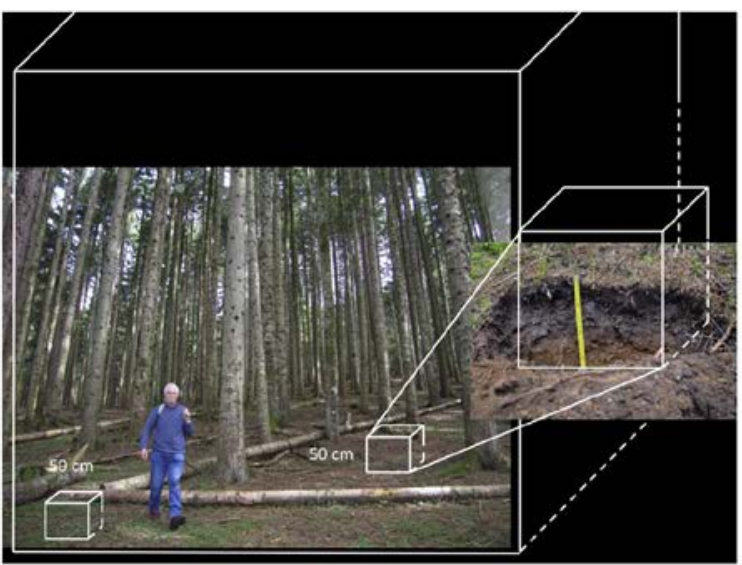

c

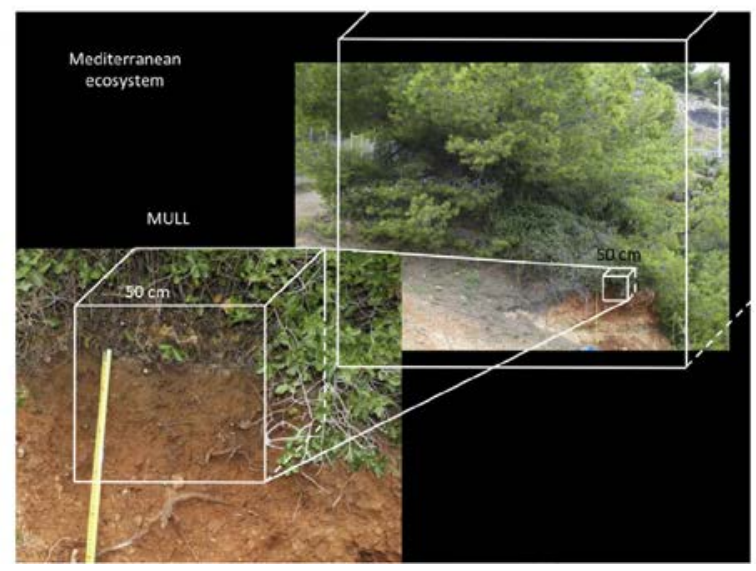

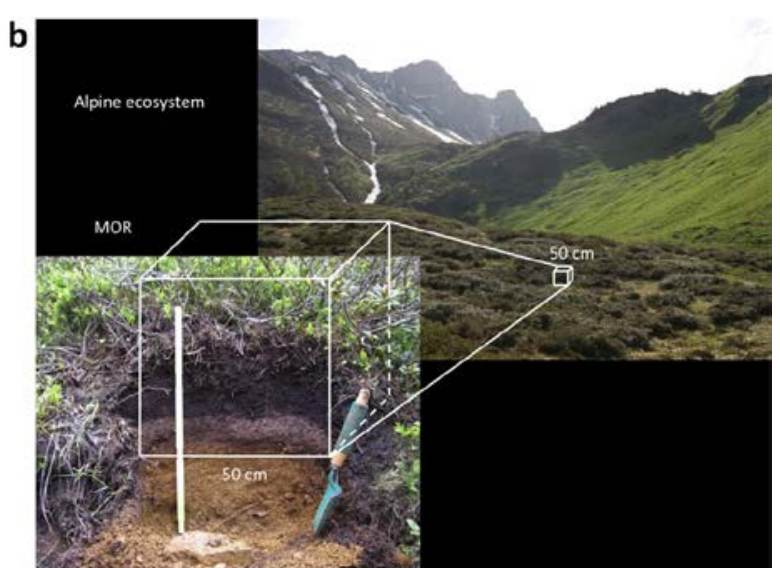

d

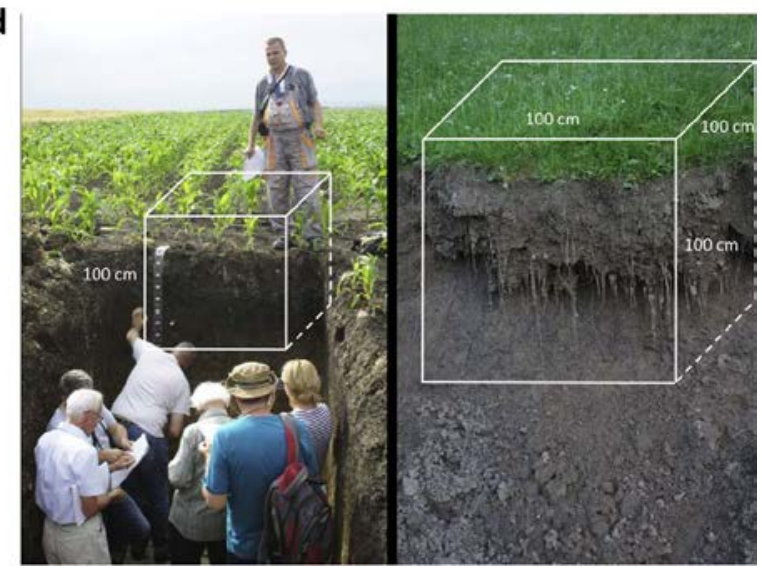

Fig. 13 